\title{
Kinon-metidi (II. dio): Fotokemijsko generiranje i razvoj primjene u fotokemoterapiji
}

\author{
Đ. Škalamera, ${ }^{*}$ A. Husak i T. Šumanovac Ramljak \\ Institut Ruđer Bošković, Bijenička cesta 54, 10000 Zagreb
}

Ovo djelo je dano na korištenje pod Creative Commons Attribution 4.0 International License

\begin{abstract}
|| Sažetak
Kinon-metidi (QM, naziv po IUPAC-u: kinometani) su reaktivni međuprodukti koji su povezani s biološkom aktivnosti brojnih prirodnih i sintetski dobivenih spojeva. Njihova aktivnost temelji se na inhibiciji enzima ili, češće, na alkilaciji/križnom povezivanju DNA. QM se mogu generirati termičkim metodama, ali veliku prednost imaju fotokemijske metode, jer pružaju mogućnost prostorne i vremenske kontrole nad njihovim stvaranjem. Za konačni cilj - primjenu u fotokemoterapiji od presudne je važnosti razvoj prekursora za generiranje QM-a. Ovim pregledom bit će dan uvid u fotokemijske metode generiranja QM-a i razvoj njihove primjene u fotokemoterapiji.
\end{abstract}

\section{\| Ključne riječi}

Kinon-metidi, reaktivni međuprodukti, fotokemijsko generiranje kinon-metida, antiproliferativna aktivnost, agensi za alkilaciju DNA, križno povezivanje DNA, fotokemoterapija

\section{Uvod}

Kinon-metidi** (engl. quinone methide, QM, naziv po IUPAC-u: kinometani) reaktivni su međuprodukti koji su često prisutni u kemiji i fotokemiji fenola i njima srodnih spojeva. ${ }^{1}$ Osim vrlo široke primjene u organskoj sintezi, ${ }^{2,3}$ važna mogućnost primjene je i u biološkim sustavima, ponajprije kao antitumorskih agensa. ${ }^{4}$ Potrebu za proučavanjem i razumijevanjem kemije QM-a, kao i studiranje njihove potencijalne primjenjivosti u biološkim sustavima pokazuju rezultati do kojih se do sada došlo na Institutu Ruđer Boškovićc ${ }^{5,6,7,8,9,10}$ i u grupi M. Freccera. ${ }^{6 a, 11}$ Kako su QM reaktivni međuprodukti kratkog vremena života, uobičajeno je da se generiraju ${ }^{3}$ iz nekog pogodnog prekursora. To se može postići upotrebom odgovarajućih reagensa ili grijanjem (sintetske ili termičke metode). ${ }^{3}$ Kako u biološkim sustavima najčešće nije baš pogodno upotrebljavati takve reagense, fotokemijske metode generiranja QM-a tu postižu veliku prednost. Iz pogodnog prekursora može se nakon pobude svjetlom određene valne duljine generirati QM. Prednost toga je da se QM generira samo tada kad se to želi i samo na mjestu gdje je osvjetljeno. Međutim, kako bi QM mogli imati praktičnu primjenu u medicini, potrebno je pronaći sustave koji bi mogli dati QM nakon pobuđivanja svjetlom u vidljivom području, idealno iznad $500 \mathrm{~nm}$, ili barem svjetlom > $350 \mathrm{~nm}$, koje ne apsorbiraju uobičajene unutarstanične molekule. Primjeri prekursora QM-a koje bi se moglo pobuditi vidljivim dijelom spektra nisu do sada opisani u literaturi.

\footnotetext{
*Autor za dopisivanje: dr. sc. Đani Škalamera

e-pošta: Djani.Skalamera@irb.hr

** lako IUPAC više ne preporučuje upotrebu naziva kinon-metid, već preporučuje kinometan, autori ovog pregleda odlučili su zadržati stari naziv kinon-metid. Razlog tome je ponajprije usklađenost ovog članka sa svom ostalom relevantnom i recentnom literaturom o kinon-metidima, koja se koristi upravo tim nazivom.
}

\section{Fotokemijske metode generiranja QM-a}

U fotokemijskim reakcijama sudjeluju vrste koje su elektronski pobuđene, zbog čega imaju znatno različitu raspodjelu elektrona u molekuli nego što je to slučaj u osnovnom stanju te je i reaktivnost u pobuđenom stanju drugačija nego u osnovnom stanju. Derivati fenola i fenilnih etera ili laktona koji podliježu ß-cijepanju najčešće se upotrebljavaju za generiranje QM-a u fotokemijskim reakcijama.

Takav tip reakcija poznat je još iz pionirskog rada Zimmermana, koji je studirao reakcije solvolize s nukleofilnim otapalom, tj. nukleofilne supstitucije skupine vezane $u$ ß-položaju u odnosu na kromofor. ${ }^{12}$ Mehanizam reakcije kod aromatskih spojeva, prema poznatim literaturnim podacima, može uključivati nastanak arilnih karbokationa, ${ }^{13}$ karbena $^{14}$ ili homolitičko cijepanje veze praćeno prijenosom elektrona. ${ }^{15}$ lako se odvijaju različitim mehanizmom od reakcija u aromatskim spojevima, ${ }^{12}$ takve reakcije uobičajene su i u fotokemiji mnogih karbonilnih spojeva. ${ }^{16} \mathrm{U}$ nastavku će biti naveden pregled reakcija fotokemijskog generiranja QM-a.

\subsection{Fotofragmentacija oksaheterocikala}

Jedna od prvih opisanih metoda fotokemijskog generiranja QM-a bila je fotofragmentacija oksaheterocikala. Chapman $i$ sur. studirali su generiranje QM-a iz benzolaktona 1, i sulfona 4. Nakon fotopobude i eliminacije male molekule ( $\mathrm{CO}$ ili $\mathrm{SO}_{2}$ ) nastaje QM, koji odmah reagira s prisutnim nukleofilnim otapalom - metanolom, dajući o-hidroksibenzil-metil-eter (3) kao produkt reakcije fotosolvolize (shema 1). U Diels-Alderovoj reakciji [4+2] cikloadicije QM-a 2 i 1,1-dimetoksieten (5) daju kroman 6, čijom izolacijom je na neizravan način dokazano postojanje QM-a kao međuprodukta. ${ }^{17}$ 


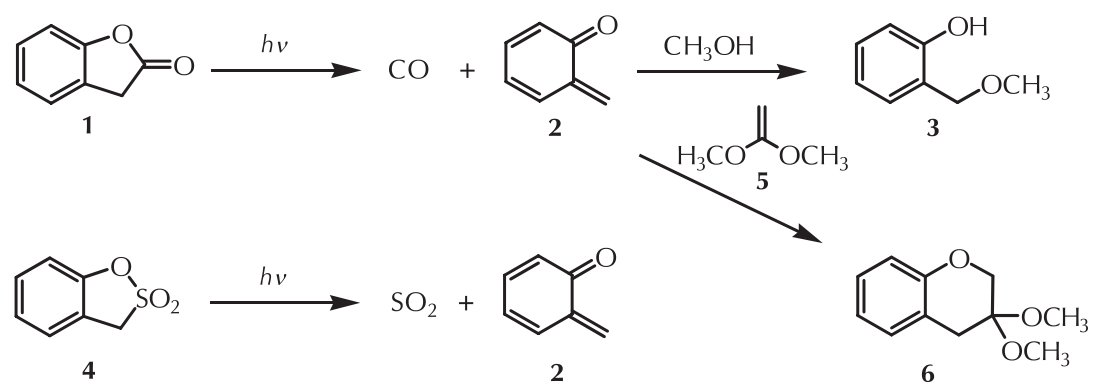

Shema 1 - Generiranje QM-a fotofragmentacijom oksaheterocikala ${ }^{17}$

Scheme 1 - Generation of QM by photofragmentation of oxaheterocycles ${ }^{17}$

Iz derivata kromena 7 također se može generirati QM. Ozračivanjem dolazi do otvaranja prstena oksaheterocikla, pri čemu nastaje QM 8 u kojem $[1,7]$ sigmatropnim pomakom vodika dolazi do rearomatizacije te u konačnici nastaje nezasićeni fenolni produkt 9 (shema 2). ${ }^{18}$

Reakciju fotofragmentacije oksaheterocikala za dizajn fotouklonjivih zaštitnih skupina (shema 3 ) iskoristili su Wang $i$ sur. ${ }^{19}$ Iz različito supstituiranih aldehida i ketona, na takav se način mogu sintetizirati odgovarajući acetali/ketali 10a-h u izvrsnim iskorištenjima (>90 \%). ${ }^{19 a}$ Supstituirani hidroksibenzilni alkohol 13 odabran je kao alkoholna komponenta pri stvaranju ketala. Tako nastali acetali/ketali vrlo su stabilni te mogu podnijeti različite reakcijske uvjete (kisele, bazne, grijanje). Ozračivanjem tako zaštićenih spojeva u smjesi $\mathrm{CH}_{3} \mathrm{CN} / \mathrm{H}_{2} \mathrm{O}$ oslobađa se aldehid, odnosno keton, a kao drugi produkt dobiva se hidroksibenzilni alkohol 13, koji se može ponovno upotrijebiti. lako za to u radu nije ponuđen izravan dokaz, mehanizam reakcije fotodeprotekcije vrlo vjerojatno uključuje međuprodukt QM 11. Uklanjanje zaštitne skupine provedeno je u veoma dobrom iskorištenju (75-90\%), te ova metoda predstavlja izvrstan način zaštićivanja aldehida ili ketona.

Wang i sur. također su razvili niz različito supstituiranih benzilnih alkohola, koji se mogu upotrijebiti kao fotouklo- njive zaštitne skupine za ortogonalnu zaštitu u sintezi, jer se selektivno uklanjaju ozračivanjem različitim valnim duljinama, ovisno o supstituentima $R^{1}-R^{3}($ slika 1$) .{ }^{19 b}$<smiles>[R]c1cc2c(c([R])c1[R])OC(CCc1ccccc1)(c1ccccc1)O2</smiles>

Slika 1 - Zaštitne skupine za aldehide i ketone koje se mogu selektivno ukloniti ozračivanjem različitim valnim duljina$\mathrm{ma}^{19 \mathrm{~b}}$

Fig. 1 - Protecting groups for aldehydes and ketons which can be selectively removed by irradiation at different wavelengths ${ }^{19 b}$

Autori su pokazali da salicilni alkoholi koji se upotrebljavaju kao zaštitne skupine (spojevi 14) mogu pri drugačijim reakcijskim uvjetima poslužiti i kao blagi oksidansi za oksidaciju alkohola u aldehide. ${ }^{19 \mathrm{c}}$

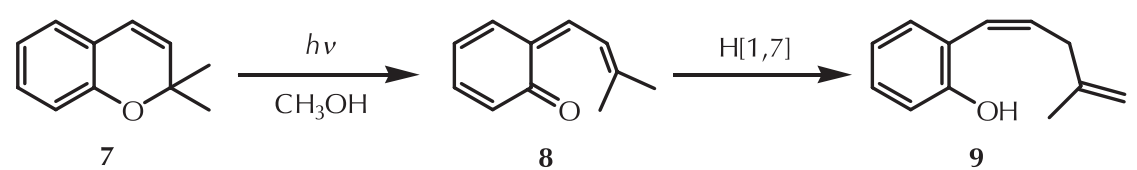

Shema 2 - Generiranje QM-a fotokemijskim otvaranjem oksaheterocikla ${ }^{18}$

Scheme 2 - Generation of QM by photochemical ring opening in oxaheterocycles ${ }^{18}$<smiles>[R]C1([R])Oc2ccc(OC)cc2C(c2ccccc2)(c2ccccc2)O1</smiles>

10a-h<smiles>CCCC[N+](C)(O)OC</smiles><smiles>COC1=CC(=C(c2ccccc2)c2ccccc2)C(=O)C=C1</smiles>

11<smiles>[R]C([R])=O</smiles>

$12 \mathrm{a}-\mathrm{h}$<smiles>COc1ccc(O)c(C(O)(c2ccccc2)c2ccccc2)c1</smiles>

13<smiles>[R]C([R])=O</smiles>

$12 a-h$

$$
\begin{aligned}
& \text { e } \mathrm{R}^{1}=\mathrm{H}, \mathrm{R}^{2}=\mathrm{p}-\mathrm{OCH}_{3} \mathrm{Ph} \\
& \text { f } \mathrm{R}^{1}=\mathrm{H}, \mathrm{R}^{2}=\mathrm{CH}_{2} \mathrm{CH}_{2} \mathrm{Ph} \\
& \text { g R } \mathrm{R}^{1}=\mathrm{H}, \mathrm{R}^{2}=\mathrm{CH}_{2} \mathrm{CH}_{2} \mathrm{Ph} \\
& \text { h R } \mathrm{R}^{1}=\mathrm{H}, \mathrm{R}^{2}=\mathrm{CH}_{2} \mathrm{CH}_{2} \mathrm{Ph}
\end{aligned}
$$

Shema 3 - Fotodeprotekcija karbonilnih spojeva ${ }^{19 a}$

Scheme 3 - Photodeprotection of carbonyl compounds ${ }^{19 a}$ 


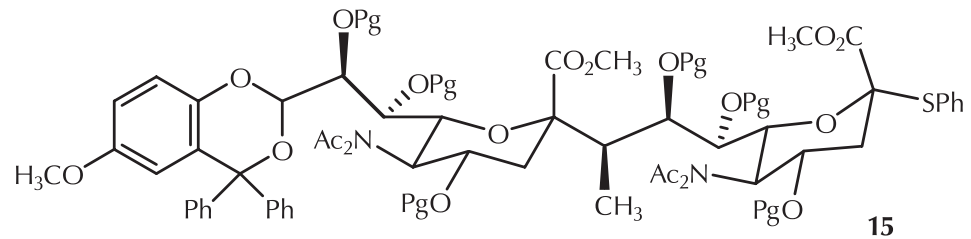

Slika 2 - Struktura disaharida neuraminske kiseline zaštićenog fotouklonjivom zaštitnom skupinom ${ }^{20}$

Fig. 2 - Structure of neuraminic acid disaccharide protected with photocage ${ }^{20}$

Linhardt sa suradnicima vrlo je uspješno upotrijebio taj tip zaštitnih skupina u sintezi disaharida neuraminske kiseline 15 (slika 2). ${ }^{20}$

\subsection{Kiselost fenola/hidroksiaromatskih spojeva u pobuđenom stanju i prijenos protona u pobuđenom stanju}

S obzirom na to da reakcije fotogeneriranja QM-a iz fenola i drugih hidroksiaromatskih spojeva uključuju proces prijenosa protona u pobuđenom stanju (ESPT), ovdje je važno reći nešto više o samom procesu. Nakon elektronske pobude, kod određenih skupina aromatskih spojeva može doći do vrlo velike promjene u kiselo-baznim svojstvima. ${ }^{21}$ Hidroksiaromatski spojevi (fenoli) i aromatski amini postaju jače kiseline, za razliku od dušikovih heteroaromata, kao što su derivati piridina, koji u pobuđenom stanju postaju jače baze. Prilikom pobuđivanja molekule dolazi do intramolekulske preraspodjele $\pi$-elektronskog oblaka (u vremenu reda veličine atosekunde), pri čemu se elektronska gustoća s kisika delokalizira u aromatski prsten. Posljedica toga je slabljenje veze $\mathrm{O}-\mathrm{H}$ te će anionski oblik koji nastaje u idućem koraku (fenolat) biti dodatno stabiliziran, a time je potaknuta i daljnja disocijacija. ${ }^{22}$ Zbog toga će vrijednost $\mathrm{p} K_{\mathrm{a}}$ pobuđenog stanja (tj. $\mathrm{p} K_{\mathrm{a}}{ }^{*}$ ) fenola biti niža od vrijednosti $\mathrm{p} K_{\mathrm{a}}$ za disocijaciju iste molekule $\mathrm{u}$ osnovnom stanju, tj. kiselost je povećana u pobuđenom stanju. Tako je primjerice vrijednost $\mathrm{p} K_{\mathrm{a}}$ 2-naftola (16) u osnovnom stanju 9,5, dok u pobuđenom stanju $\mathrm{pK}^{*}$ iznosi 2,8, što je promjena od 7 redova veličine u konstanti disocijacije (shema 4). ${ }^{22}$ lako su promjene vrijednosti $p K_{a}$ obično od 4 do 10 redova veličine, u literaturi je opisano i postojanje spojeva koji su superfotokiseline. Primjer takvog spoja je 5,8-dicijano-2-naftol koji je u pobuđenom stanju kiselina $\mathrm{s} \mathrm{pK} K_{\mathrm{a}}=-4,5$, što je do danas najniža određena vrijednost $\mathrm{p} K^{*} \cdot{ }^{23}$

Ako se kiselo i bazno mjesto u nekoj molekuli nalaze u neposrednoj blizini, tada nakon pobude može doći do intramolekulskog prijenosa protona (engl. excited state

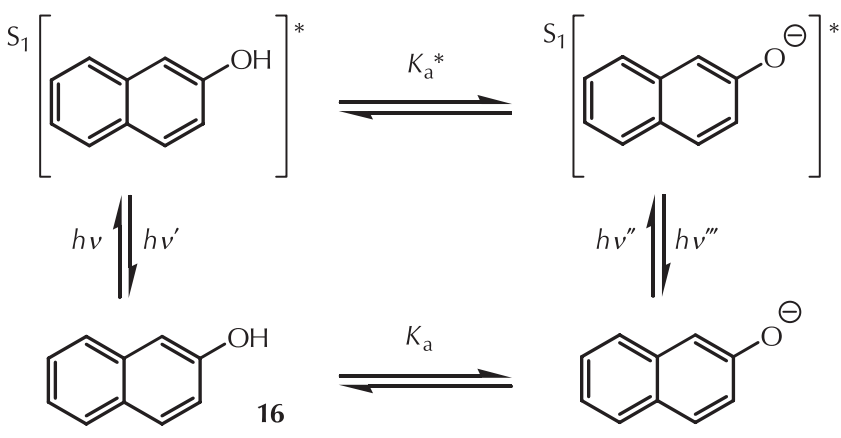

Shema 4 - Disocijacija 2-naftola u osnovnom i pobuđenom stanju; ilustrativni prikaz Försterova termodinamičkog ciklusa

Scheme 4 -Dissociation of 2-naphthol in ground and excited state; illustrative representation of the Förster thermodynamic cycle

intramolecular proton transfer, ESIPT), ako nisu u blizini, tada se prijenos protona može odvijati samo intermolekulski (ESPT). Prema mehanizmu, prijenos protona može biti intrinzički (izravno između dva bliska mjesta u molekuli, pravi ESIPT), usklađeni prijenos dvaju protona (npr. kod 7-azaindola) te fototautomerizacija s uključenim molekulama protičnog otapala. ${ }^{24}$

\subsection{Fotodehalogenacija derivata fenola}

Jednu od prvih sistematičnih studija fotokemije fenola i naftola koji sadrže benzilne supstituente proveli su Seiler i Wirz. ${ }^{25}$ Istraživali su fotokemiju različito supstituiranih trifluormetilfenola, gdje je fluor zapravo na benzilnom položaju, i pokazali su da u singletnom pobuđenom stanju dolazi do fotodisocijacije fenola. Nakon eliminacije fluorida nastaje QM 18 koji reakcijom s prisutnom vodom daje benzilni alkohol 19. Proces se ponavlja dok se ne zamijene svi atomi fluora, te na kraju rezultira salicilnom kiselinom 20 (shema 5). Navedene reakcije odvijaju se s vrlo visokim kvantnim prinosima (do 0,8$)$.

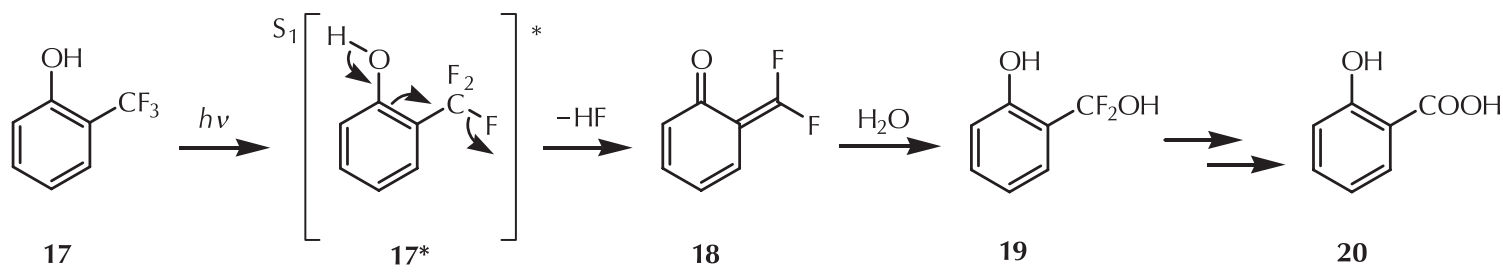

Shema 5 - Generiranje QM-a iz o-trifluormetilfenola $(\mathbf{1 7})^{25}$

Scheme 5 - Generation of QM from o-trifluoromethylphenol $(\mathbf{1 7})^{25}$ 


\subsection{Fotodehidratacija derivata fenola}

QM se mogu generirati i reakcijama fotodehidratacije hidroksimetilfenola i sličnih derivata. Prvi primjer takve reakcije opisao je Gomberg u radu objavljenom 1913. godine. ${ }^{26}$ On je primijetio da uzorci suhog hidroksibenzilfenola 21, koji su izloženi sunčevoj svjetlosti, čak i kratko, postaju žuti. Isto se događalo i u benzenskoj otopini. Te promjene Gomberg je pripisao nastanku QM-a 22 kao rezultatu eliminacije vode (shema 6), ali sam mehanizam reakcije ostao je nepoznat još više od pola stoljeća.<smiles>Oc1ccc(C(O)(c2ccccc2)c2ccccc2)cc1</smiles>

21<smiles>O=C1C=CC(=C(c2ccccc2)c2ccccc2)C=C1</smiles>

22
Shema 6 - Fotodehidratacija u Gombergovom spoju $\mathbf{2 1}^{26}$ Scheme 6 - Photodehydratation in Gomberg compound $\mathbf{2 1}{ }^{26}$

Lewis sa svojim suradnicima ponovno je studirao tu reakciju 1970-ih godina. ${ }^{27}$ Iz kristalne strukture spoja 21 (slika 3) otkriveno je zašto je fotodehidratacija u čvrstom stanju moguća: fenolna i benzilna $\mathrm{OH}$-skupina su u vodikovoj vezi unutar kristala, te u pobuđenom stanju dolazi do prijenosa protona s fenolne na benzilnu $\mathrm{OH}$-skupinu, što je praćeno dehidratacijom.

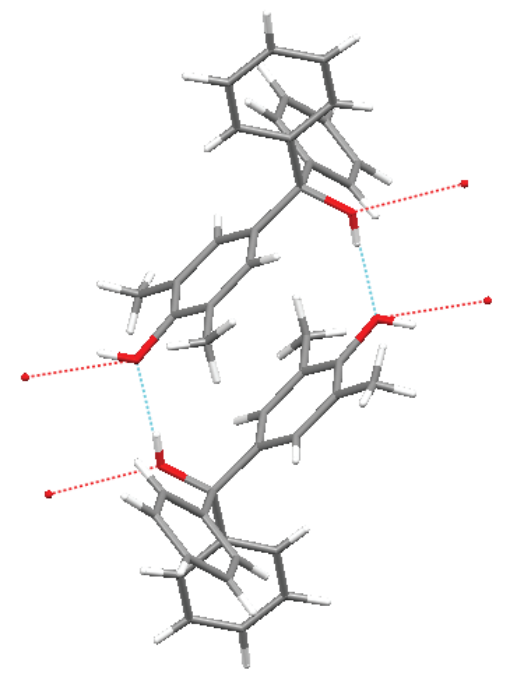

Slika 3 - Kristalna struktura spoja 21 otkriva zašto je moguća fotodehidracija u čvrstom stanju ${ }^{27}$

Fig. 3 - Crystal structure of compound $\mathbf{2 1}$ reveals why photodehydration in solid state is possible ${ }^{27}$

Sličnu reakciju dehidratacije 1970-ih godina studirao je Hamai (shema 7). ${ }^{28}$<smiles>Oc1ccccc1C(O)(c1ccccc1)c1ccccc1</smiles>

23

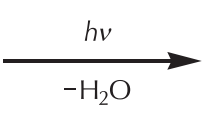<smiles>O=C1C=CC=CC1=C(c1ccccc1)c1ccccc1</smiles>

24
Shema 7 - Reakcija fotodehidratacije u derivatu trifenilmetanola koju je studirao Hamai ${ }^{28}$

Scheme 7 - Reaction of photodehydratation in triphenylmethanol derivative studied by Hamai ${ }^{28}$

Prvi koji je sistematično proučavao fotokemiju hidroksibenzilnih alkohola bio je Wan sa svojim suradnicima te je njegov doprinos na ovom području danas temelj za razumijevanje tih reakcija. ${ }^{29}$ On je studirao jednostavne hidroksibenzilne alkohole (shema 8) te utvrdio da u reakciji fotolize alkohola $\mathbf{2 5}$ u pobuđenom stanju dolazi do prijenosa protona praćenog dehidratacijom. Pri tome nastaje QM 2 koji je vrlo reaktivna vrsta te odmah reagira s prisutnim nukleofilnim otapalom - metanolom dajući adukt 26.

Fotosolvoliza, odnosno ugradnja metoksi-skupine, događa se i kod etera 27, ali uz znatno niži kvantni prinos (shema 8b). Razlog tome je što u spoju $\mathbf{2 7}$ ne može doći do prijenosa protona u pobuđenom stanju, te je izlazak benzilne $\mathrm{OH}$-skupine znatno teži. Pri tome kod spoja 27 vjerojatno dolazi do heterolize veze $\mathrm{CH}_{2}-\mathrm{OH}$, pri čemu se generira benzilni kation, koji u reakciji s metanolom daje adukt 28, a također je moguća i homoliza te veze, pri čemu nastaju radikali koji prijenosom elektrona daju benzilni kation. ${ }^{29}$ Nekoliko godina kasnije, Wan i sur. su detektirali QM 2 LFP-om. ${ }^{30}$ (a)

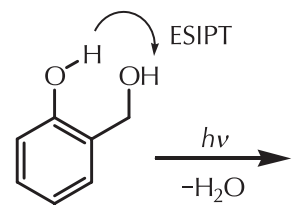

25<smiles>C=C1C=CC=CC1=O</smiles>

2<smiles>COCc1ccccc1O</smiles>

26 (b)

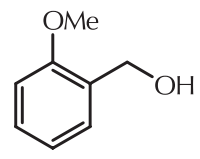

27

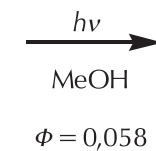

$\phi=0,058$<smiles>COCc1ccccc1OC</smiles>

28
Shema 8 - Fotokemija (a) hidroksibenzilnog alkohola 25, (b) etera hidroksibenzilnog alkohola 27

Scheme 8 - Photochemistry of (a) hydroxybenzyl alcohol 25, (b) ether derivative of hydroxybenzyl alcohol 27

Wan i sur. studirali su i fotokemiju niza $O-, m$ - i $p$ - hidroksibenzilnih alkohola 23,29-31 koji na benzilnom položaju imaju vodik, jednu ili dvije fenilne skupine (slika 4). ${ }^{31}$ 
<smiles>[R]C([R])(O)c1ccccc1O</smiles>

$29 a-b$ $23 \mathrm{R}^{1}=\mathrm{R}^{2}=\mathrm{Ph}$<smiles>[R]C([R])=C1C=CC=CC1=O</smiles>
$24 R^{1}=R^{2}=P h$<smiles>[R]C([R])(O)c1cccc(O)c1</smiles>

$30 \mathrm{a}-\mathrm{c}$<smiles>[R]C(C)c1cccc([O-])c1</smiles>

$31 \mathrm{a}-\mathbf{c}$<smiles>[R]C([R])(O)c1ccc(O)cc1</smiles>

a $\mathrm{R}^{1}=\mathrm{R}^{2}=\mathrm{H}$

b $\mathrm{R}^{1}=\mathrm{H}, \mathrm{R}^{2}=\mathrm{Ph}$

c $R^{1}=R^{2}=P h$

Slika 4 - Strukture različito supstituiranih hidroksibenzilnih fenola i odgovarajućih QM-a ${ }^{31}$

Fig. 4 -Structures of differently substituted hydroxybenzylphenols and corresponding QM ${ }^{31}$

Utvrdili su da do stabilizacije odgovarajućeg QM-a, a time i znatnog produljenja vremena života i kvantnog prinosa njihova nastajanja, dolazi uvođenjem fenilnog supstituenta na benzilni položaj (tj. na metilenski položaj odgovarajućeg QM-a) (tablica 1).

Tablica 1 - Kvantni prinosi reakcije fotometanolize i vremena života međuprodukata QMa fotogeneriranih iz prekursora $29 a-b$ i 23

Table 1 - Quantum yield of photomethanolysis reaction and lifetimes of QM intermediates photogenerated from precursors $\mathbf{2 9} \mathbf{a}-\mathbf{b}$ and $\mathbf{2 3}$

\begin{tabular}{c|c|c|c}
\hline $\begin{array}{c}\text { Prekursor QM-a } \\
\text { QM precursor }\end{array}$ & $\begin{array}{c}\text { Struktura QM-a } \\
\text { QM structure }\end{array}$ & $\Phi$ & $\tau / \mathrm{s}$ \\
\hline $\mathbf{2 9 a}$ & $\mathbf{3 2 a}$ & 0,23 & $2 \cdot 10^{-3}$ \\
$\mathbf{2 9 b}$ & $\mathbf{3 2 b}$ & 0,46 & 0,4 \\
$\mathbf{2 3}$ & $\mathbf{2 4}$ & 0,76 & $-{ }^{\mathrm{a}}$ \\
\hline
\end{tabular}

a Tehnikom LFP opažen je tranzijent, ali je dugoživući pa nije moguće pratiti kinetiku njegovog nestajanja.

a Transient was observed by LFP, but it is too long-living, which makes it impossible to monitor the kinetics of its decay.

Basarić $i$ sur. su kao nastavak tog istraživanja sintetizirali spojeve 35a-c, koji su na benzilnom položaju supstituirani adamantanom (slika 5). Adamantan zbog steričkih smetnji ometa napad nukleofila na QM pa on ima dulje vrijeme života. ${ }^{5}$

Najveći kvantni prinos nastanka QM-a, u svim do sad navedenim primjerima, je kod $o$-supstituiranih derivata. Razlog tome leži u postojanju vodikove veze između fenolne $\mathrm{OH}$-skupine (kiselo mjesto) i benzilne $\mathrm{OH}$-skupine (bazično mjesto), pa se prijenos protona uzduž te vodikove veze u pobuđenom stanju (ESIPT) odvija vrlo učinkovito. Prijenos protona praćen je izlaskom molekule vode (dehidratacijom). U slučajevima kad su $\mathrm{OH}$-skupine na fenilnom i benzilnom položaju udaljene $(\operatorname{kod} m$ - i $p$ - supstituiranih
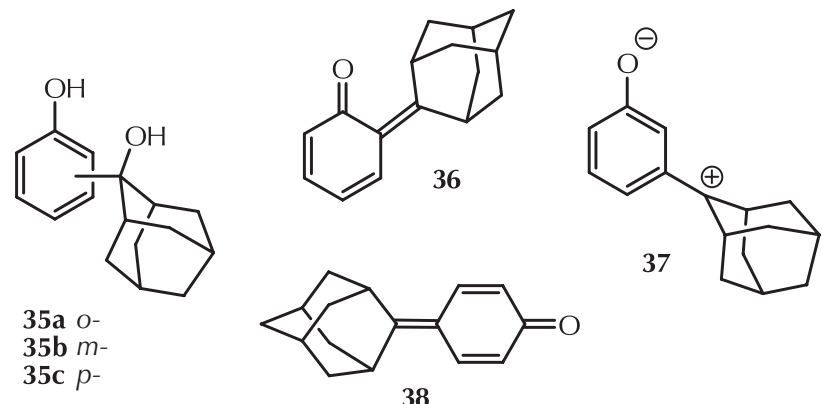

Slika 5 - Strukture hidroksibenzilnih alkohola 35a-c i odgovarajućih QM 36-38 s adamantanskim supstituentom ${ }^{5}$

Fig. 5 - Structures of hydroxybenzyl alcohols $\mathbf{3 5 a - c}$ and corresponding QMs 36-38 with adamantane substituent ${ }^{5}$

derivata), ESIPT se ne može dogoditi, već se prijenos protona odvija uz posredovanje otapala (ESPT).

Wan i sur. u nastavku su svojih istraživanja studirali dehidrataciju i ESIPT ili otapalom (vodom) posredovani ESPT na većim kromofornim sustavima. Pripravili su seriju $O_{-}$, $m$ - i $p$-supstituiranih hidroksibifenila 39-42 (shema 9) te utvrdili da svi spojevi podliježu fotokemijskim reakcijama solvolize preko međuprodukta QM-a. Spoj 39 u fotoke-

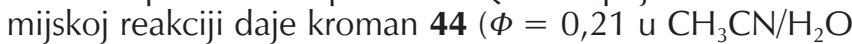
(1:1)) (shema 9a), a njegovo nastajanje objašnjeno je primarnim nastankom QM-a $\mathbf{4 3}$ kod kojeg zbog blizine metilenske i karbonilne skupine dolazi do elektrociklizacijske reakcije. Reakcija intramolekulske elektrociklizacije je vrlo brza, pa je zbog toga vrijeme života QM 43 kratko. Slična je situacija i kod spoja $\mathbf{4 0}$ iz kojeg nastaje kratkoživući QM 45 zwitterionske strukture, a dalje, intramolekulskom ciklizacijom nastaju derivati fluorena $\mathbf{4 6 a}$ i $\mathbf{4 6 b}$ uz nešto malo produkta solvolize $\mathbf{4 7}$ (5\%) (shema 9b). Kod fotolize para supstituiranih spojeva 41 i 42 (shema 9c i d) ne može doći do intramolekulskih reakcija u odgovarajućim QM 48, odnosno 50, pa su oni karakterizirani duljim vremenom života (400 ns, odnosno $65 \mu$ s), što je autorima omogućilo njihovu karakterizaciju LFP-om. Zanimljivo je da je kvantni 
(a)

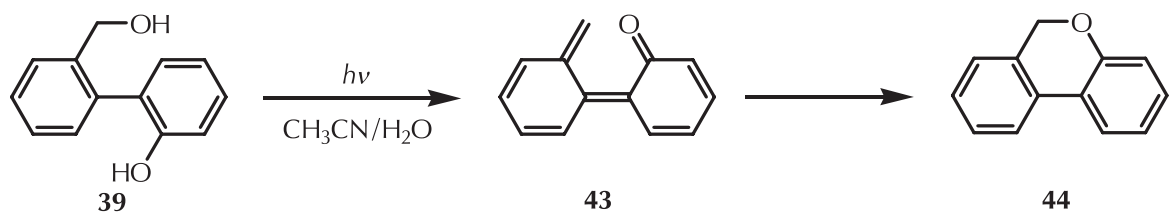

(b)

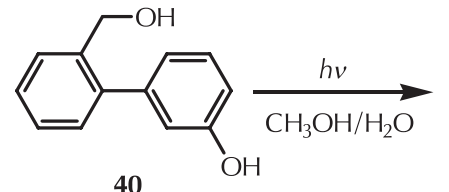<smiles>[CH2-]c1ccccc1-c1ccc(C)c(O)c1</smiles>

45<smiles>CC(C)(C)O</smiles><smiles>COCc1ccccc1-c1cccc(O)c1</smiles>

(c)

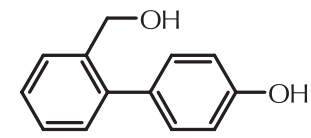

41

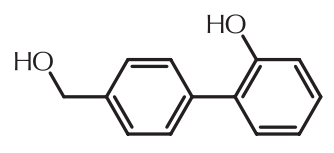

42
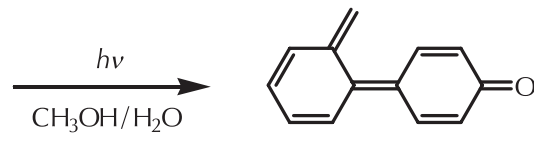

48

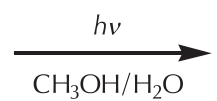

$\mathrm{CH}_{3} \mathrm{OH} / \mathrm{H}_{2} \mathrm{O}$

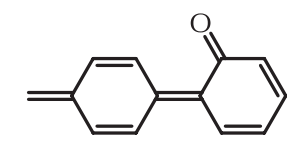

50

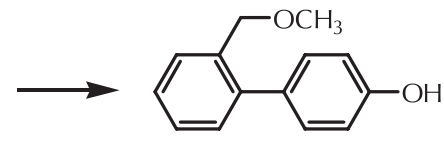

49

Shema 9 - Serija bifenilnih prekursora QM-a i njihove reakcije fotodehidratacije i solvolize

Scheme 9 - Series of biphenyl precursors of QMs and their reaction of photodehydratation and solvolysis

prinos fotosolvolize za spoj 41 oko 10 puta veći nego što je to slučaj za spoj $\mathbf{4 2}(\boldsymbol{\Phi}=0,23$, odnosno 0,026$){ }^{32}$

U istraživanjima koja su uslijedila, Wan $i$ sur. proširili su kromoforni sustav te su studirali reakciju fotodehidratacije u naftalenskim derivatima 52-54 (slika 6a), ${ }^{32}$ u bifenilima 55-577a,33 (slika 6b), gdje je kromoforni sustav dodatno povećan uvođenjem fenilnog supstituenta na benzilni položaj te u terfenilnim derivatima 58 i $\mathbf{5 9}^{34}$ (slika 6c). Naftalenski derivati dali su vrlo kratkoživuće QM, što je uzrokovano vrlo učinkovitim nastajanjem kromana te iz tog razloga QM nisu mogli biti studirani LFP-om. Supstitucija (a)<smiles>OCc1ccccc1-c1c(O)ccc2ccccc12</smiles>

52

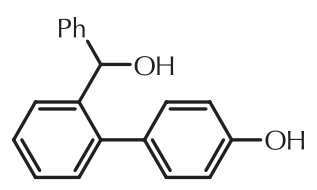

55<smiles>OCc1ccc2ccccc2c1-c1c(O)ccc2ccccc12</smiles>

53

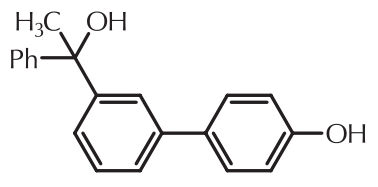

56<smiles>OCc1ccc2ccccc2c1-c1ccccc1O</smiles>

54

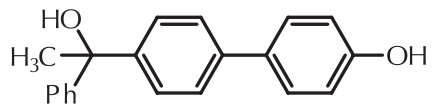

57

(c)
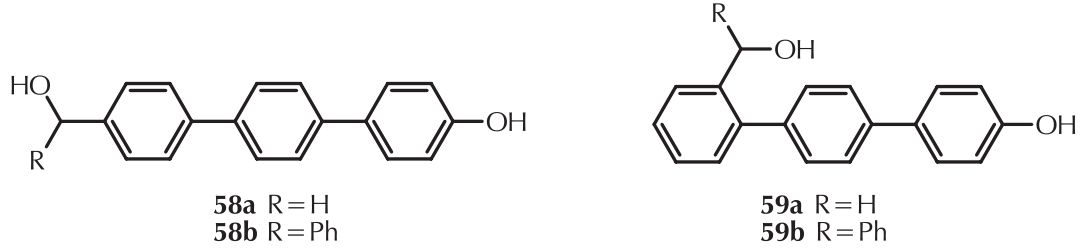

59a $\mathrm{R}=\mathrm{H}$

$59 \mathrm{~b} R=\mathrm{Ph}$

Slika 6 - (a) Naftalenski, ${ }^{32}$ (b) bifenilni ${ }^{7 a, 33}$ i (c) terfenilni ${ }^{34}$ derivati koji u reakciji fotodehidratacije daju QM

Fig. 6 - (a) Naphthalene, ${ }^{32}$ (b) biphenyl $\mathrm{l}^{7 \mathrm{a}, 33}$ and (c) terpheny $\mathrm{l}^{34}$ derivatives which deliver QMs in photodehydratation reaction 
benzilnog položaja fenilom (55-57) produljila je vremena života odgovarajućih QM-a, kao i kvantni prinos reakcije fotosolvolize (za fotoreakciju spoja 23 prikazanu na shemi 8 kvantni prinos je 0,23, dok za istu fotoreakciju kod spoja 55 iznosi 0,41). Kod terfenilnih derivata (58 i 59) primijećena je reakcija fotosolvolize, što indicira postojanje QM-a kao međuprodukta, no oni nastaju s vrlo niskim kvantnim prinosima i kratkoživući su te nisu mogli biti okarakterizirani LFP-om. ${ }^{34}$

Popik $^{35}$ i Freccero ${ }^{11 a}$ također su studirali reakciju fotodehidratacije kod naftalenskih derivata. S obzirom na to da povećani kromoforni sustav pruža mogućnosti generiranja QM-a svjetlošću valne duljine 350 nm, generiranje QM-a iz takvih derivata je od osobitog interesa za biološku primjenu QM-a. Freccero je pokazao da se, zbog postojanja intramolekulske vodikove veze između susjednog karbonila i fenolne $\mathrm{OH}$-skupine, QM može učinkovitije generirati $(\Phi=0,47)$ iz derivata BINOL-a 60 (shema 10), iako je kraćeživući ( $\tau=200 \mu \mathrm{s})$, od odgovarajućeg naftalenskog QM $61(\tau=4-8 \mathrm{~ms}){ }^{35}$

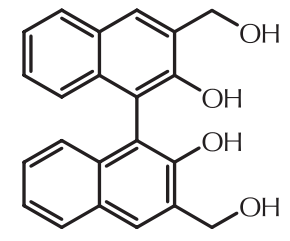

60

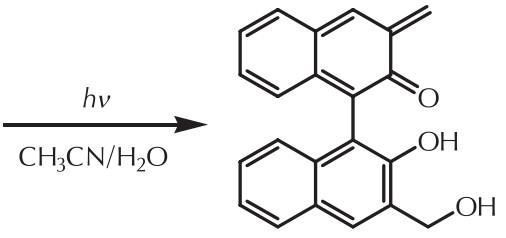

61
Shema 10 - Fotodehidratacija kod derivata BINOL-a $\mathbf{6 0}^{11 a}$ Scheme 10 - Photodehydration in BINOL derivative $\mathbf{6 0}^{11 a}$

Popik je LFP-om studirao reakciju dehidratacije derivata 2-naftola 62 i 63 te je utvrdio da odgovarajući QM 66 i 67 ( $\tau=4-8 \mathrm{~ms}$ ) nastaju stupnjevitim mehanizmom iz nekih kraćeživućih vrsta ( $\tau=10 \mu$ s), koje je pripisao naftoksetnim strukturama 64 i 65 (shema 11). ${ }^{35} \mathrm{U}$ nastavku svojih istraživanja Popik je primijenio mogućnost generiranja QM-a iz naftalenskih derivata za dizajniranje fotouklonjivih zaštitnih skupina za alkohole, fenole i karboksilne kiseline, ${ }^{36}$ ali i za modifikacije čvrstih površina i fotolitografiju. ${ }^{37}$

Meier je u svom preglednom radu ${ }^{38}$ teorijskim računima pokazao da su QM stabilnije vrste od svojih veznih izomera benzokseta (za oko $20 \mathrm{~kJ} \mathrm{~mol}^{-1}$ ), pa su time i prevladavajuće vrste u ravnoteži (shema 12). Može se očekivati da su naftokseti dosta slični benzoksetima po ponašanju i stabilnosti, te se asignacija tranzijentnih apsorpcijskih spektara u radu Popika ${ }^{35}$ stoga može dovesti u pitanje.

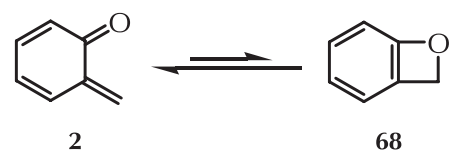

Shema 12 - Ravnoteža između QM-a i benzokseta Scheme 12 - Equilibrium between QM and benzoxete

S obzirom na to da su QM i benzokseti vrlo reaktivne vrste, za njihovu detekciju pri sobnoj temperaturi nužne su tranzijentne spektroskopske tehnike kao što je LFP. Kako bi se reaktivni međuprodukti održali stabilnima dovoljno dugo da ih se može okarakterizirati spektroskopskim tehnikama, jedno od rješenja je njihov studij pri jako niskim temperaturama, tj. pri kriogenim uvjetima (tipično $10 \mathrm{~K}$ ). Pri tim uvjetima nema dovoljno energije da bi se prešla energetska barijera potrebna za kemijsku reakciju te vrste koje su inače vrlo reaktivne mogu egzistirati vrlo dugo. Iz tog razloga Tomioka i sur. fotokemijski su generirali roditeljski benzokset $\mathbf{6 8} \mathrm{u}$ argonskoj matrici pri $10 \mathrm{~K}$ i studirali njegovu fotoizomerizaciju u QM 2 i obrnuto (shema 13). ${ }^{39}$ Uspješno su snimili IR spektre tih međuprodukta i usporedili ih s teorijski izračunatim, te time izravno dokazali njihove strukture. Vrlo sličnu fotoravnotežu između 4,6-dimetilbenzokseta i 4,6-dimetil-o-QM pri 7,6 K u argonskoj matrici studirali su nešto kasnije Solomon i Wentrup sa suradnicima. Postojanje QM-a i benzokseta, osim eksperimentom, potkrijepili su i teorijskim računima. ${ }^{40}$ (a)<smiles>OCc1cc2ccccc2cc1O</smiles>

62<smiles>OCc1c(O)ccc2ccccc12</smiles>

63

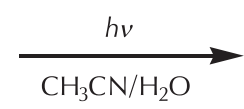

64

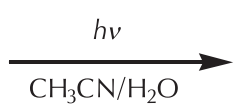<smiles>C=C1C=c2ccccc2=CC1=O</smiles>

66<smiles>c1ccc2c3c(ccc2c1)OC3</smiles><smiles>C=C1C(=O)C=Cc2ccccc21</smiles>

67

Shema 11 - Fotodehidratacija u derivatima 2-naftola 62 i $63^{35}$

Scheme 11 - Photodehydration in derivatives of 2-naphthol $\mathbf{6 2}$ and $\mathbf{6 3}^{35}$ 
<smiles>N#Cc1ccccc1O</smiles>

70

$\downarrow \begin{aligned} & >300 \mathrm{~nm} \\ & -\mathrm{N}_{2}\end{aligned}$<smiles>C=Cc1ccccc1O</smiles>

71

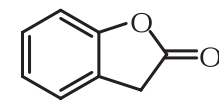

72

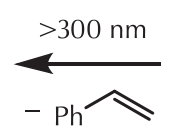

$-\mathrm{Ph} \rightleftharpoons$

(1)
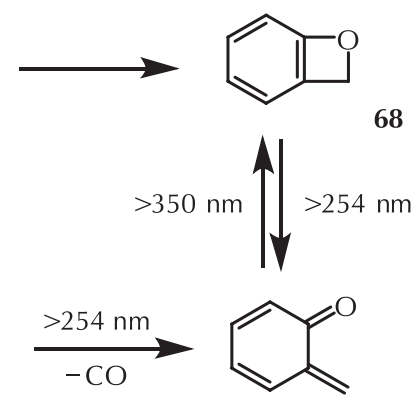<smiles>C=C1C=CC=CC1=O</smiles>

2
Shema 13 - Reakcijski niz kojim su Tomioka i sur. generirali roditeljski benzokset 68 i QM $2^{39}$

Scheme 13 - Reactions in which Tomioka and co-workers generated parent benzoxete $\mathbf{6 8}$ and QM $\mathbf{2}^{39}$

\subsubsection{Fotoeliminacije octene kiseline}

Fotoeliminaciju octene kiseline iz derivata 73 i 74 (slika 7) studirali su Kresge $i$ sur. U pobuđenom stanju dolazi do prijenosa protona s $\mathrm{OH}$-skupine fenola na acetilnu skupinu vezanu na benzilni položaj, slijedi eliminacija octene kiseline i nastanak odgovarajućeg o-QM-a 2,, ${ }^{41}$ odnosno roditeljskog $p-\mathrm{QM}-\mathrm{a}$ 74a. ${ }^{42}$ Ovaj pristup generiranju QM-a omogućio je po prvi put detekciju roditeljskog $p$-QM 74a LFP-om. ${ }^{42}$

\subsubsection{Fotoeliminacije amina i amonijevih soli}

Novu metodu generiranja o-QM-a u vodenim otopinama, uz ozračivanje valnim duljinama većim od $300 \mathrm{~nm}$, razvili su Saito $i$ sur. ${ }^{43} \mathrm{U}$ tu svrhu sintetizirali su Mannichove<smiles>CC(=O)OCc1ccccc1O</smiles>

73<smiles>CC(=O)OCc1ccc(O)cc1</smiles><smiles>C=C1C=CC(=O)C=C1</smiles>

Slika 7 - Acetatni prekursori QM-a ${ }^{41,42}$ Fig. 7 - Acetate precursors of $\mathrm{QM}^{41,42}$

baze derivata fenola (75), bifenila (76 i 77) i naftalena (78) (slika 8) te su proveli fotokemijske reakcije deaminacije u kojima nastaju odgovarajući QM. Reakcije su provodili u prisutnosti etil-vinil-etera i kao produkte izolirali derivate kromana u dobrim iskorištenjima (shema 14). Prisutnost QM-a kao međuprodukta u reakcijama nisu dokazali tranzijentnom spektroskopijom, nego samo neizravno, prema produktima fotoreakcije.

Godine 2005. objavljen je rad u kojem su Matsumoto $i$ sur. iz naftalenskih derivata $\mathbf{8 1}$ i fenantrenskih derivata $\mathbf{8 2}$ (slika 9) generirali QM u vodenim otopinama te su u prisutnosti različito supstituiranih vinilnih etera (etil, izobutil, 2-hidroksietil) dobivali različito supstituirane derivate kromana. Fotogeneriranje QM-a studirali su dodatno i u anionskim i neutralnim micelama. ${ }^{44}$<smiles>[R16]Cc1c(O)ccc2ccccc12</smiles><smiles>[R16]Cc1c(O)c2ccccc2c2ccccc12</smiles>

81a $R=M e$

82a $R=M e$

82b $\mathrm{R}=\mathrm{Et}$

82c $\mathrm{R}=i-\operatorname{Pr}$

Slika 9 - Aminometil(hidroksi)arenski prekursori $\mathrm{QM}-\mathrm{a}^{44}$ Fig. 9 - Aminomethyl(hydroxy)arene precursors of $\mathrm{QM}^{44}$<smiles>CN(C)Cc1ccccc1O</smiles>

75<smiles></smiles>

76<smiles>CN(C)Cc1cc(-c2ccc(O)c(CN(C)C)c2)ccc1O</smiles>

77<smiles>CN(C)Cc1c(O)ccc2ccccc12</smiles>

78

Slika 8 - Mannichove baze - prekursori za fotokemijsko generiranje QM-a ${ }^{43}$

Fig. 8 - Mannich bases - precursors for photochemical generation of $\mathrm{QM}^{43}$<smiles>CNCc1cc(-c2ccccc2)ccc1O</smiles>

$76 a$<smiles>C=C1C=C(c2ccccc2)C=CC1=O</smiles>

79<smiles>CCO/C=C\CC1CCc2cc(-c3ccccc3)ccc2O1</smiles>

80

Shema 14 - Generiranje QM-a iz Mannichove baze bifenila i njegova Diels-Alderova reakcija s etil-vinil-eterom ${ }^{43}$

Scheme 14 - Generation of QM from biphenyl Mannich base and their Diels-Alder reaction with ethyl-vinyl-ether ${ }^{43}$ 
U radu autori navode i potencijalnu primjenu QM-a dobivenih iz spojeva 81 i 82 u biološkim sustavima, ali iako se radi o vrlo obećavajućim spojevima, nažalost nisu provedena nikakva biološka ispitivanja. ${ }^{44}$

Prema radu Freccera i sur., ozračivanje kvaterne amonijeve soli 83 dobivene metilacijom Mannichove baze ima znatno veći kvantni prinos generiranja QM $2(\Phi=0,98)$ od odgovarajućeg ranije spomenutog alkoholnog derivata $\mathbf{2 5}$ $(\phi=0,23)^{29 b}$ (shema 15). ${ }^{45 a}$

Prednost amonijeve soli (npr. spoj 83), za razliku od alkoholnih derivata, kakav je npr. spoj 25, osim vrlo učinkovitog generiranja QM-a, je i u tome što je topljiva u vodi. Potrebno je naglasiti još jednu prednost ovakvih spojeva, a to je nepostojanje nukleofilnog centra - slobodnog aminskog dušika, kao što je to slučaj u Mannichovim bazama (npr. 75-78, 81 i 82). Slobodni amin reagira s QM-om i time mu skraćuje vrijeme života, a to je ovdje izbjegnuto. Učinkovito generiranje dugoživućih QM-a omogućilo je autorima studij reaktivnosti QM-a u čistoj vodi s različitim nukleofilima - aminokiselinama: glicinom, serinom, cisteinom, lizinom i tirozinom te s peptidom glutationom. lako su odredili i konstante brzine reakcije s raznim nukleofi- lima, ${ }^{45 a}$ mehanizam reakcije deaminacije u pobuđenom stanju do danas nije istražen.

Zhou i sur. primijenili su fotoeliminaciju amonijevih soli dobivenih iz Mannichovih baza za generiranje QM-a na bifenilnom derivatu $\mathbf{8 4},{ }^{46}$ dok su Freccero $i$ sur. istu reakciju primijenili na derivatima bipiridina 85, ${ }^{47}$ BINOL-a 86-88 ${ }^{11 a}$ i naftalena $\mathbf{8 9}^{11 c}$ (slika 10). Reakcije fotoeliminacije iz derivata 85-88 odvijaju se s visokim kvantnim prinosima te su odgovarajući QM studirani LFP-om. S obzirom na visoke kvantne prinose generiranja QM-a iz amonijevih soli, kao i topljivosti soli u vodi te pozitivnog naboja molekule, ta metoda pokazala se vrlo korisnom za upotrebu u biološkim sustavima, npr. za križno povezivanje molekule DNA. ${ }^{11}$

Fotoeliminaciju u konjugatu fenola i naftalimida $\mathbf{9 0}$ također su studirali Freccero i sur. Mehanizam fotokemijske reakcije nastajanja QM-a uključuje tripletno pobuđeno stanje naftalimidnog kromofora, gdje se u prvom koraku događa prijenos elektrona, nakon čega se deprotonira fenolni radikal-kation dajući fenoksil-radikal. Povratnim prijenosom elektrona nastaje fenolat koji deaminacijom učinkovito generira odgovarajući QM. ${ }^{48}$ S obzirom na to da je pokazano<smiles>CN(C)Cc1ccccc1O</smiles>

83

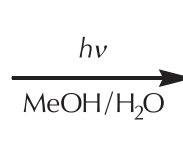

$\phi=0,98$

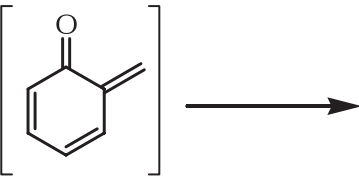

2<smiles>COCc1ccccc1O</smiles>

26

Shema 15 - Fotogeneriranje QM-a iz kvaterne amonijeve soli dobivene metilacijom Mannichove baze ${ }^{45 a}$

Scheme 15 - Photogeneration of QM from quaternary ammonium salt which is obtained by methylation of Mannich base ${ }^{45 a}$

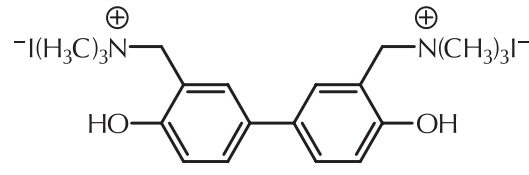

84<smiles>CN(C)Cc1cc2ccccc2c(-c2c(O)ccc3ccccc23)c1O</smiles>

86<smiles>COC(C)(C)Cc1ccc2cc(O)ccc2c1</smiles>

89<smiles>CN(C)Cc1nc(-c2ccc(O)c(C[NH3+])n2)ccc1O</smiles>

85<smiles>CN(C)Cc1ccc2c(-c3c(O)ccc4cc(C[N+](=O)[O-])ccc34)c(O)ccc2c1</smiles>

88

Slika 10 - Kvaterne amonijeve soli Mannichovih baza korištene za fotogeneriranje QM-a'11a,11c,46,47

Fig. 10 - Quaternary ammonium salts of Mannich bases used for photogeneration of QMs ${ }^{11 a, 11 c, 46,47}$ 


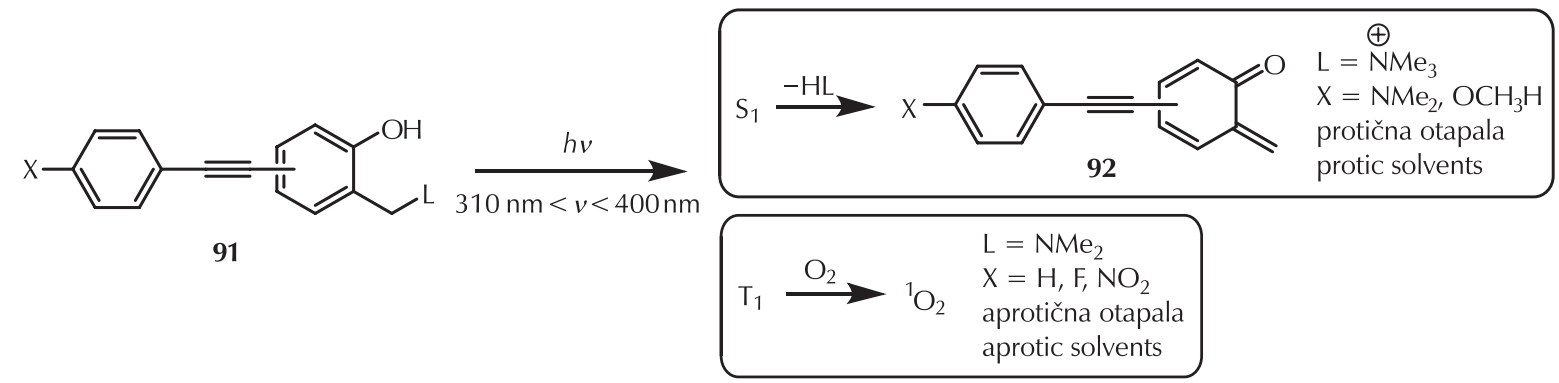

Shema 16 - Fotokemija 4- i 5-ariletinilnih Mannichovih baza i odgovarajućih soli51 Scheme 16 - Photochemistry of 4- and 5-arylethynyl Mannich bases and corresponding salts ${ }^{51}$

kako konjugati QM-a i naftalimida mogu selektivno alkilirati gvanidinske kvadruplekse, taj derivat ima vrlo velik potencijal za primjenu u biološkim sustavima. ${ }^{49,50}$

Nedavno su Freccero i sur. objavili sintezu i fotokemiju 4- i 5-ariletinilnih Mannichovih baza i njihovih odgovarajućih soli topljivih u vodi (91). ${ }^{51}$ Pokazali su da kod takvih spojeva nakon pobude zračenjem valne duljine između 310 i $400 \mathrm{~nm}$ može doći do dva procesa (shema 16). Prvi se događa u protičnim otapalima iz singletnog pobuđenog stanja i rezultira generiranjem QM-a koji može poslužiti kao alkilirajući agens. Drugi proces događa se iz tripletnog pobuđenog stanja, i to u aprotičnim otapalima. Pri tome spoj 91 djeluje kao tripletni senzibilizator na kisik, što rezultira nastankom singletnog kisika. S obzirom na to da se iz spoja može generirati QM bliskovidljivim zračenjem i da može djelovati kao tripletni senzibilizator na kisik, radi se o strukturi koja je vrlo dobar lead spoj za daljnju optimizaciju u svrhu primjene u fotokemoterapiji (QM), odnosno fotodinamičkoj terapiji (singletni kisik).

\subsubsection{Fototautomerizacije i ESIPT na ugljikov atom}

Wirz i sur. su 1977. objavili prvi primjer fotokemijskog generiranja QM-a reakcijom fototautomerizacije u naftokinonu 93. ${ }^{52}$ Reakcija se odvija preko tripletnog pobuđenog stanja, gdje dolazi do enolizacije i nastanka QM-a 94 (shema 17).<smiles>Cc1cccc2c1C(=O)C=CC2=O</smiles>

93<smiles>C=c1cccc2c1=C(O)C=CC2=O</smiles>

94
Shema 17 - Generiranje QM-a u reakciji fototautomerizacije ${ }^{52}$ Scheme 17 - Generation of QM in phototautomerization reaction $^{52}$

Rokita je taj tip reakcije upotrijebio za generiranje QM-a iz antrakinon-oligonukleotidnog konjugata 95 (slika 11), koji je upotrijebio za križno povezivanje molekule DNA na vrlo specifičnom dijelu, komplementarnom s faktorom prepoznavanja u derivatu 95. ${ }^{53}$

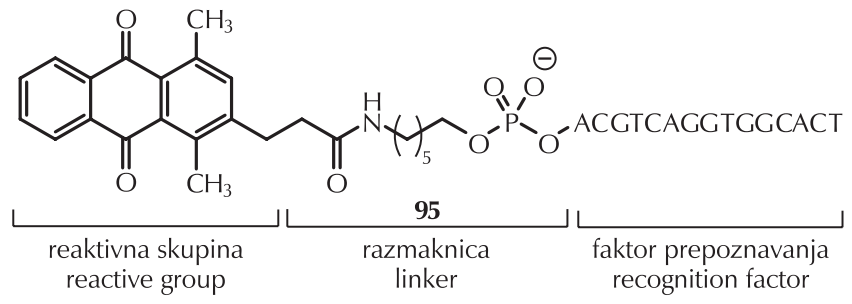

Slika 11 - Antrakinon-oligonukleotidni konjugat upotrijebljen za fotoinduciranu alkilaciju DNA ${ }^{53}$

Fig. 11 -Anthraquinone-oligonucleotide conjugate used for photoinduced alkylation of DNA ${ }^{53}$

Roditeljski p-QM 74a može se generirati iz derivata 4-hidroksiacetofenona 96 u foto-Favorskiijevoj reakciji. Reakcija se odvija iz tripletnog pobuđenog stanja biradikalskog tipa, gdje nakon dekarbonilacije nastaje QM 74a. ${ }^{54}$ Također je studirana reakcija fotogeneriranja QM-a 98 iz 4-hidroksiacetofenona 97 (slika 12). ${ }^{55}$<smiles>[X]CC(=O)c1ccc(O)cc1</smiles>

96<smiles>CC(=O)c1ccc(O)cc1</smiles>

97<smiles>CC(O)=C1C=CC(=O)C=C1</smiles>

98
Slika 12 - Derivati 4-hidroksiacetofenona koji daju QM u fotokemijskoj reakcijij ${ }^{54 a}$

Fig. 12 - Derivatives of 4-hydroxyacetophenone which delivers QM in photochemical reaction ${ }^{54 a}$

ESPT su u reakcijama fototautomerizacije hidroksistirenskih derivata 99-102 studirali Yates, ${ }^{56}$ Wan $^{57}$ i Arai/Lewis ${ }^{27,58}$ sa svojim suradnicima (slika 13). 


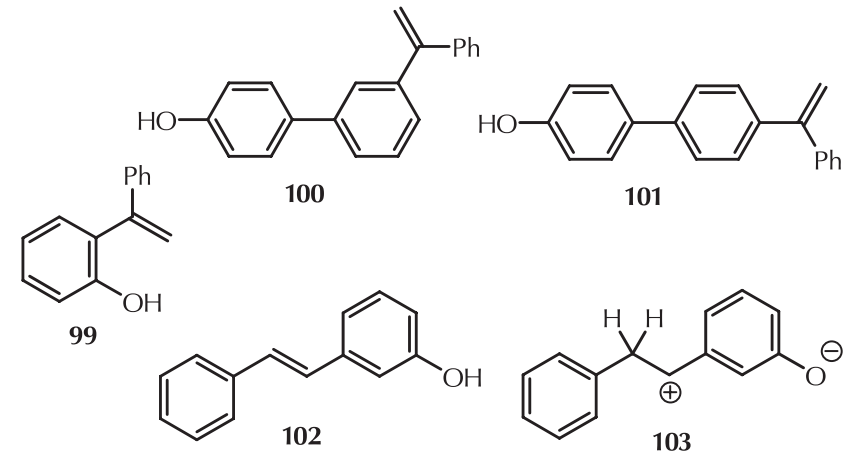

Slika 13 - Hidroksistirenski derivati koji daju QM reakcijama fototautomerizacije ${ }^{33,57,58}$

Fig. 13 - Hydroxystyrene derivatives which deliver QM by phototautomerization ${ }^{33,57,58}$

Kvantni prinos fotohidratacije spoja $99 \mathrm{u} \mathrm{CH}_{3} \mathrm{CN} / \mathrm{H}_{2} \mathrm{O}$ $(1: 1)$ iznosi $0,13 \pm 0,02$ (shema 18)..$^{57 a}$<smiles>C=C(c1ccccc1)c1ccccc1O</smiles>

99<smiles>C/C(=C1/C=CC=CC1=O)c1ccccc1</smiles>

104<smiles>CC(C)(O)c1ccccc1O</smiles>

105
Shema 18 - Fototautomerizacija u o-hidroksistirenskom derivatu $99^{57 a}$

Scheme 18 - Phototautomerization in o-hydroxystyrene derivative $99^{57 a}$

I u meta-derivatu 106 također se događa fotohidratacija. Naravno, u tom slučaju reakcija se odvija preko zwitteriona 107 (shema 19), i ta je reakcija učinkovitija $(\phi=0,10 \pm 0,02)^{57 \mathrm{~b}, \mathrm{c}}$ od analogne reakcije fotohidratacije spoja $101(\Phi=0,013 \pm 0,005)^{57 b, c} z$ bog dobro poznatog meta-efekta u fotokemiji. ${ }^{12}$

Reakcije fotohidratacije u različito supstituiranim derivatima hidroksistilbena studirali su Arai $i$ sur. te su utvrdili da je reakcija specifična - reaktivan je samo m-izomer 102. On podliježe fototautomerizaciji dajući zwitterionski QM $103(\Phi=0,15)$, koji adicijom vode daje produkt fotohidratacije. ${ }^{58}$

U nastavku svojih istraživanja Wan i sur. studirali su reakcije u kojima je dvostruka veza na koju se prenosi proton dio aromatskog sustava. ${ }^{59}$ Tako su na primjeru 2-fenilfenola 109 pokazali da pri ozračivanju u otopini $\mathrm{CH}_{3} \mathrm{CN} / \mathrm{D}_{2} \mathrm{O}$ dolazi do ugradnje deuterija na $O$ - i $p$ - položaje fenilnog prstena (shema 20). QM 110 može nastati u čvrstom stanju, protičnom i aprotičnom otapalu, dok je za nastanak QM-a 111 nužno protično otapalo koje sudjeluje u prijenosu protona.

Slične reakcije studirane su kod 1 -naftola, ${ }^{60}$ naftil-fenolnih derivata (shema 21a), ${ }^{61}$ BINOL-a, ${ }^{62}$ terfenilnih derivata, ${ }^{63}$ pirenskih derivata, ${ }^{64} \mathrm{i}$ antracena ${ }^{65}$ (shema 21b). Zanimljivo je kako je upravo reakcija fototautomerizacije kod BINOL-a glavni uzrok njegove racemizacije ako je izložen svjetlu. ${ }^{62}$

Yates $^{66 a}$ i Freccero studirali su i primjer ESIPT-a s fenolne $\mathrm{OH}$-skupine na susjednu trostruku vezu alkina 120 (shema 22). ${ }^{66 \mathrm{~b}}$ Freccero je LFP-om okarakterizirao vinilidenski QM 121, a određene su i konstante brzine reakcije QM-a 121 s raznim nukleofilima (aminima) te izolirani odgovarajući adukti.

Ta reakcija ima svoju potencijalnu primjenu u sintezi derivata tipa 122/123 u slučajevima kad to nije moguće provesti na neki jednostavniji način.

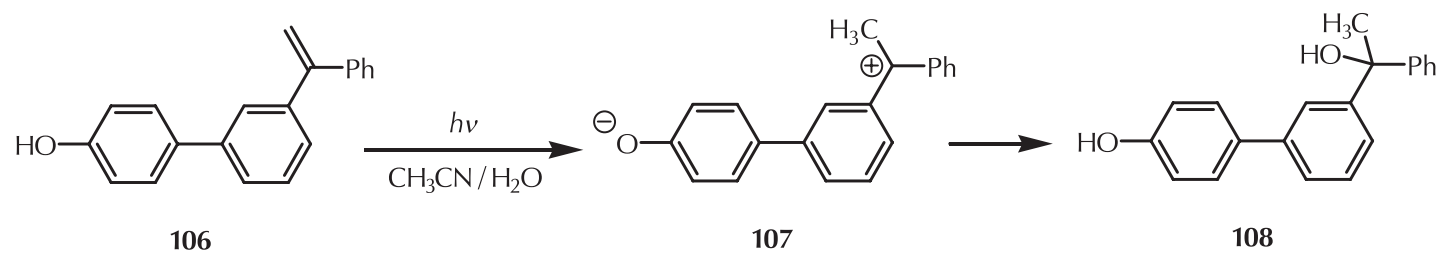

Shema 19 - Fotohidratacija u spoju 106 $\mathbf{1 0 6}^{57 \mathrm{~b}, \mathrm{c}}$

Scheme 19 - Photohydration in compound $\mathbf{1 0 6}^{\text {57b,c }}$<smiles>Oc1ccccc1-c1ccccc1</smiles>

109

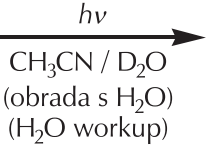

( $\mathrm{H}_{2} \mathrm{O}$ workup)

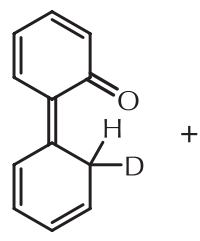

110<smiles>O=C1C=CC=CC1=C1C=CC([18OH])C=C1</smiles><smiles>[2H]c1ccccc1-c1ccccc1O</smiles>

112<smiles>Oc1ccc(-c2ccccc2O)cc1</smiles>

D 113

Shema 20 - ESPT u spoju 109, selektivna ugradnja deuterija u aromatski prsten kad je reakcija provedena u deuteriranom protičnom otapalu ${ }^{59}$

Scheme 20 - ESPT in compound 109, selective incorporation of deuterium in aromatic ring when the reaction was carried out in deuterated protic solvent ${ }^{59}$ 
(a)<smiles>Oc1c(-c2ccccc2)ccc2ccccc12</smiles>

114

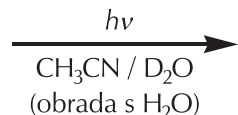

$\left(\mathrm{H}_{2} \mathrm{O}\right.$ workup)

(b)<smiles>Oc1ccccc1-c1c2ccccc2cc2ccccc12</smiles>

117

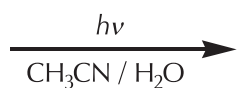<smiles>O=C1C=CC=CC1=C1c2ccccc2Cc2ccccc21</smiles>

$+$<smiles>[2H]c1cccc([2H])c1-c1ccc2ccccc2c1O</smiles>

116

Shema 21 - (a) ESIPT u naftil-fenolnom derivatu 114, ${ }^{61 \mathrm{~b}}$ (b) fotohidratacije u antracenskom derivatu $119^{65}$ Scheme 21 - (a) ESIPT in naphthtyl-phenol derivative 114, ${ }^{61 \mathrm{~b}}$ (b) photohydration in anthracene derivative $\mathbf{1 1 9}^{65}$<smiles>[R]C#Cc1ccccc1O</smiles>

120<smiles>[R]C=C1C=CC(C)=CC1=O</smiles>

121<smiles>CCCNC(=O)c1ccccc1O</smiles>

122<smiles>NCC(=O)c1ccccc1O</smiles>

123

Shema 22 - ESIPT na alkinsku trostruku vezu i reakcije nastalog vinilidenskog QM-a s nukleofilom (aminom) Scheme 22 - ESIPT on alkyne triple bond and reactions of formed vinylidene QM with nucleophile (amine)

\section{Biološka aktivnost kinon-metida}

\subsection{Mehanizmi biološke aktivnosti kinon-metida}

QM su spojevi čija se biološka aktivnost temelji na njihovoj sposobnost alkiliranja prirodnih makromolekulskih nukleofila prisutnih u stanici: aminokiselina, ${ }^{45,67}$ peptida i proteina, ${ }^{68,69}$ nukleotida, ${ }^{70}$ mogućnosti inhibiranja aktivnosti nekih enzima ${ }^{71}$ te alkilaciji i križnom povezivanju
DNA. ${ }^{11 b, 46,47,70}$ Fotokemijskim reakcijama unutar žive stanice mogu se pripraviti QM, što je vrlo pogodno za primjenu u biološkim sustavima, npr. za tretman karcinoma. ${ }^{4}$ Sposobnost križnog povezivanja DNA svrstava QM u potencijalne antitumorske terapeutike. ${ }^{72,73}$ Neki antineoplastični agensi, kao što je mitomicin C (124), temelje svoju antiproliferativnu aktivnost na međuproduktima QM-a (127) koji nastaju kao posljedica metabolizma lijeka (shema 23). ${ }^{75}$

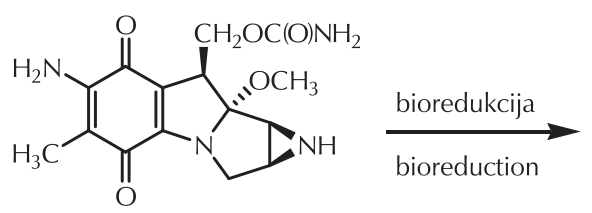

124<smiles>CO[C@]12C(COC(N)=O)c3c(O)c(N)c(C)c(O)c3N1C[C@@H]1N[C@H]12</smiles>

125

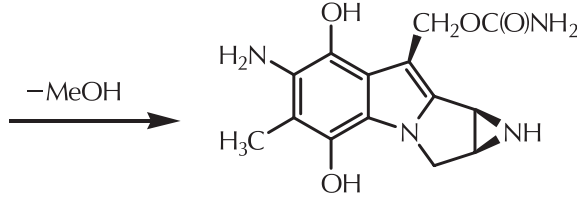

126

mitomicin C mytomicin C<smiles>Cc1c(N)c(O)c2c(COC(N)=O)c3n(c2c1O)C[C@H](N)[C@H]3ON</smiles><smiles>C=CC</smiles>

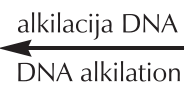<smiles>CC1=C(N)C(=O)c2c(CC(N)=O)c3n(c2=C1O)C[C@H](N)C=3</smiles>

127<smiles>C=C1c2c(O)c(N)c(C)c(O)c2[N+]2C[C@@H](N)[C@H](O)C12</smiles>

129

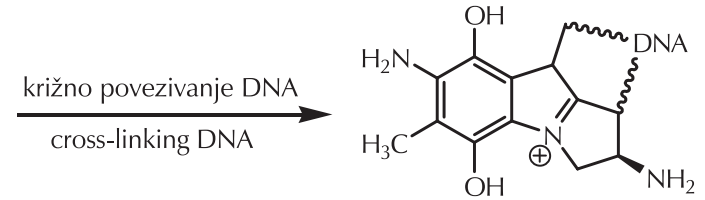

130

Shema 23 - Mehanizam biološke aktivnosti mitomicina C (124) $)^{4,74}$

Scheme 23 - Mechanism of biological activity of mitomycin C (124) 4$)^{4,74}$ 
Do nedavno se smatralo da antraciklinski antibiotici, kao što je npr. daunorubicin (131), temelje svoju biološku aktivnost na križnom povezivanju DNA s QM-ima koji se generiraju u metabolizmu lijeka (shema 24). ${ }^{75}$
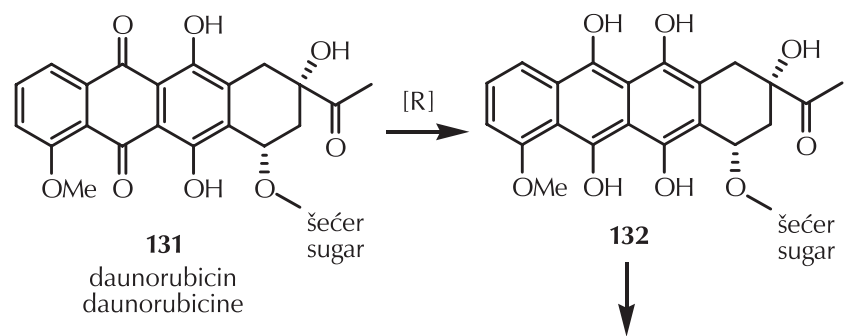

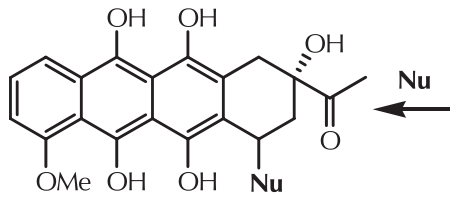

134<smiles></smiles>

133
Shema 24 - Metaboličko generiranje QM-a iz daunorubicina $\mathbf{( 1 3 1}^{73 a}$

Scheme 24 - Metabolic generation of QM from daunorubicine $(\mathbf{1 3 1})^{73 a}$

Daunorubicin 131 je prirodni spoj koji je prvi put izoliran iz bakterije Streptomyces peucetius, a upotrebljava se pod registriranim imenom DaunoXome ${ }^{\circledR}$ kao lijek za liječenje nekih oblika leukemije. ${ }^{75}$ On ima sposobnost interkaliranja između parova baza u DNA gdje nakon generiranja QM-a 133 može križno povezati DNA, te inhibirati njezinu replikaciju. ${ }^{76}$ Križnim povezivanjem DNA inhibira se enzim topoizomeraza II, koji ima ulogu razdvajanja lanaca pri replikaciji. ${ }^{77}$ To je ujedno i mehanizam djelovanja svih lijekova koji križno povezuju DNA. Neka novija istraživanja (Koch i sur.) govore u prilog tome da kod antraciklina za križno povezivanje DNA nisu odgovorni QM, već formaldehid koji nastaje metabolički. ${ }^{78}$ Međutim, čak i sami autori tvrde da je podrijetlo formaldehida nastalog u metabolizmu nepoznato; njegovo postojanje u živoj stanici potkrepljuju samo ispitivanjima in vitro, gdje postoji mogućnost generiranja formaldehida iz nekih prisutnih agenasa. Predloženi mehanizam biološke aktivnosti koji uključuje formaldehid iz tih se razloga može dovesti u pitanje. Osim spomenutih mitomicina C i antraciklina, u upotrebi su još i CC 1065, derivati duokarmicina i analozi ciklopropilpiroloindola, ${ }^{79}$ koji također svoje djelovanje temelje na QM-ima kao međuproduktima.

\subsection{Prednosti fotokemijskih metoda generiranja QM}

Fotokemijske metode generiranja QM-a imaju višestruke prednosti nad termičkim metodama, ponajviše zbog toga što ne zahtijevaju upotrebu nikakvog dodatnog reagensa. Za razliku od uobičajenih reagensa koji se upotrebljavaju u kemiji, fotoni ne generiraju neželjene sporedne produkte koji su rezultat kemijske transformacije reagensa. Stoga se fotoni s pravom mogu smatrati reagensima bez traga (engl. traceless reagent). ${ }^{80}$ Fotokemijskim generiranjem QM-a može se postići prostorna i vremenska kontrola nad njihovim stvaranjem, što je veoma pogodno za njihovu primjenu u biološkim sustavima, primjerice kao fotokemoterapeutika. ${ }^{4}$

\subsection{Fototerapija}

Fototerapija je u svojim jednostavnijim oblicima u primjeni već više od 3000 godina. Stari Egipćani, Kinezi i Indijanci primjenjivali su ju pri tretmanu bolesti kože. Tako su pomoću biljnih ekstrakata koji su sadržavali furokumarine (psoralene) uspijevali liječiti vitiligo i leukodermu te postizali repigmetaciju kože nakon nanošenja preparata i izlaganja suncu. Razvojem moderne znanosti uspješno su okarakterizirani psoraleni kao aktivni fotosenzibilizatori u navedenim ekstraktima i utvrđen je mehanizam njiho-

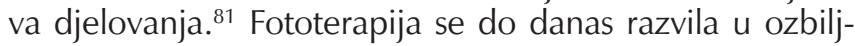
nu granu medicine, s mnogo poznatih lijekova za razne bolesti i stanja. Većina fototerapeutika koji su u upotrebi oslanjaju se na singletni kisik, koji se u živom tkivu generira uz pomoć svjetla i nekog pogodnog agensa - fotosenzibilizatora. Takva terapija naziva se fotodinamička terapija i najčešće se primjenjuje kod liječenja makularne degeneracije uzrokovane starenjem, ali i za liječenje tumora. ${ }^{82}$ Zbog potrebe za izvorom svjetlosti metode fototerapije možda djeluju invazivno, ali s obzirom na razvijenost opreme (lampe, laseri, diodni laseri, LED, optička vlakna, difuzori) fototerapija je minimalno invazivna te je oporavak znatno kraći nego kod klasičnih operativnih zahvata. ${ }^{83,84}$ Djelovanje fotokemoterapeutika temelji se na jednostavnom principu koji je prikazan na slici 14. Metoda se sastoji u tome da se pacijentu oboljelom od karcinoma daje agens koji sam po sebi nema biološku aktivnost u primijenjenoj koncentraciji. Poželjno je da taj agens ima svojstvo akumuliranja u tumorskom tkivu. Nakon fotokemijske aktivacije agensa, i to samo na mjestu gdje se želi postići antiproliferativna aktivnost (u tumorskom tkivu), dolazi do izazivanja nepopravljive štete na stanicama tumora, što za posljedicu ima njihovo odumiranje te u konačnici dolazi do nestanka tumora, a time i izlječenja.

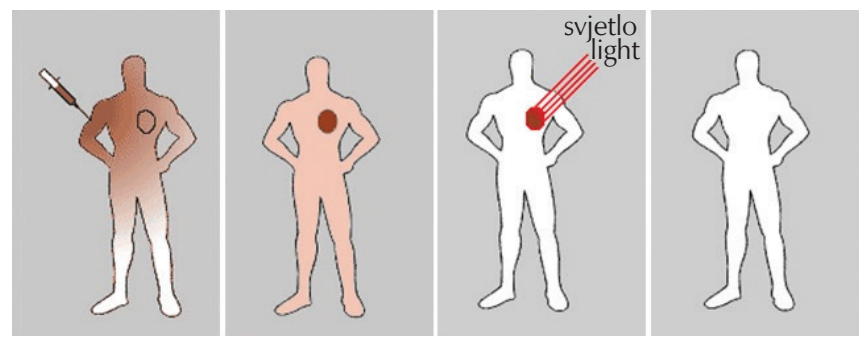

Slika 14 - Osnovni princip djelovanja fototerapeutika Fig. 14 - Basic principle of action of phototherapeutics

Na temeljima tih principa mogao bi se kao fotokemoterapeutik upotrijebiti lijek koji je po strukturi prekursor QM-a. Moguće je generirati QM na točno željenom mjestu i u točno željeno vrijeme, ozračivanjem. Fotogenerirani QM, zbog svoje reaktivnosti, mogli bi uzrokovati nepopravljivu štetu u stanici i dovesti do smrti stanice, odnosno tkiva tu- 
mora. Valna duljina apsorpcije prekursora jedan je od iznimno važnih zahtjeva za primjenu fotogeneriranih QM-a u biološkim sustavima. S obzirom na to da i samo tkivo apsorbira svjetlost, idealna valna duljina za pobuđivanje iznosila bi oko $650 \mathrm{~nm}$ (crveno svjetlo). Crveno svjetlo ujedno ima i najveću moć prodiranja kroz tkivo. Međutim, kako iznad $350 \mathrm{~nm}$ ne apsorbiraju uobičajene stanične molekule (DNA, RNA, kromoforne aminokiseline), primjena fotogeneriranih QM-a nije nužno ograničena apsorpcijom samog tkiva, pa je zasad kroz literaturu o biološki primjenjivim fotogeneriranim QM-ima jedan od glavnih ciljeva dizajn prekursora s apsorpcijskim maksimumom iznad $350 \mathrm{~nm}$. Drugi vrlo važan uvjet za primjenu fotogeneriranih QM-a je omjer konstanti brzine reakcije QM-a s ciljanim biološki važnim nukleofilima (DNA, proteini) i vodom (shema 25).

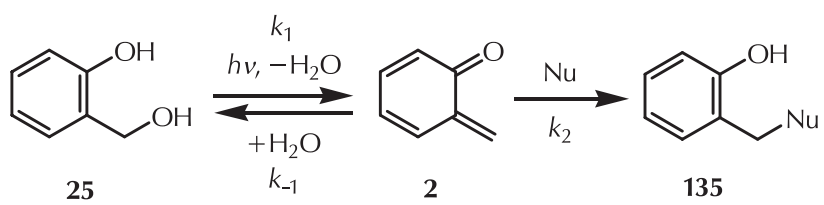

Shema 25 - Fotogeneriranje QM-a, povratna reakcija uzrokovana reakcijom s vodom i nastajanje adukta u reakciji s nukleofilom

Scheme 25 - Photogeneration of QM, reversible reaction with water and formation of aduct in the reaction with nucleophile

Kako bi QM mogao reagirati s nukleofilima u što manjim koncentracijama i kako bi bio selektivniji u tim reakcijama, cilj je postizanje što duljeg vremena života QM-a. Također je poželjno da reakcija fotogeneriranog QM-a s nukleofilima ima visok kvantni prinos, s obzirom na to da se na taj način smanjuje potrebno vrijeme ozračivanja.

\subsection{Primjena fotogeneriranih kinon-metida u biološkim sustavima}

Reaktivnost QM-a s aminokiselinama, ponajprije s cisteinom istraživali su Bolton, ${ }^{67}$ Freccero $^{45}$ i Popik ${ }^{68}$ sa svojim suradnicima. Nađeno je da se reakcija sa serinom može primijeniti za inhibiciju enzima. ${ }^{46,47,85}$ Također je pokazano da se QM mogu upotrijebiti i za obilježavanje proteina u svrhu istraživanja protein-ligand ili protein-protein interakcija. ${ }^{68,86}$ Veoma dobro je istražena reaktivnost fotogeneriranih QM-a s nukleinskim kiselinama. QM može alkilirati nukleinsku kiselinu na fosfatnoj okosnici i na samoj nukleobazi. S obzirom na to da reakcije $s$ fosfatnom okosnicom nisu toliko zanimljive i selektivne kao što mogu biti reakcije s bazama DNA, u literaturi je opisan relativno mali broj takvih reakcija. Skibo i sur. pokazali su da derivati aziridinil-kinona mogu alkilirati DNA na fosfatnoj okosnici. ${ }^{87}$ Turnbull je studirao reaktivnost $p$-QM-a s modelnim spojevima - dialkilfosfatima u reakciji nastajanja trialkilfosfa$\mathrm{ta}^{88,89}$ te je dizajnirao derivat $\mathbf{1 3 6}$ koji zbog spontane reakcije laktonizacije nakon vezanja fosfata daje derivat 138, što povećava brzinu i učinkovitost nastajanja trialkilfosfata (shema 26).

Reakcije QM-a s deoksinukleozidima i nukleinskim kiselinama studirao je Rokita sa suradnicima, ${ }^{70}$ pri čemu je utvrdio koja su reaktivna mjesta na pojedinoj bazi DNA (označavanje i numeriranje prikazano je na slici 15). ${ }^{90}$<smiles>[R]n1cnc2c(N)ncnc21</smiles>

139<smiles>[R]n1ccc(N)nc1=O</smiles>

141<smiles>[R]n1cnc2c(=O)[nH]c(N)nc21</smiles>

$\mathrm{dC}$

140<smiles>[R]n1cc(C)c(=O)[nH]c1=O</smiles>

142
Slika 15 - Potencijalna alkilacijska mjesta na purinskim i pirimidinskim nukleobazama. Zadebljano su označena nukleofilna mjesta koja mogu napadati na QM. ${ }^{91}$

Fig. 15 - Potential alkylation places on purine and pyrimidine nucleobases. Nucleophilic positions which can attack QM are in bold font. ${ }^{91}$<smiles>[R]C1=C(CCC(=O)OC)C(=O)C(C)=C/C1=C\CNC(=O)OC</smiles>

136a $\mathrm{R}=\mathrm{H}$

136b $\mathrm{R}=\mathrm{CH}_{3}$<smiles>[R]c1c(C(CNCC(C)(C)C)OP(=O)(OC(C)(C)C)OC(C)(C)C)cc(C)c(O)c1CCC(=O)OC</smiles>

137a $\mathrm{R}=\mathrm{H}$

$137 \mathbf{b} \mathrm{R}=\mathrm{CH}_{3}$<smiles>[R]c1c(C(CNC(=O)OC)OP(=O)(OCCCC)OC(C)(C)C)cc(C)c2c1CCC(=O)O2</smiles>

138a $\mathrm{R}=\mathrm{H}$

138b $\mathrm{R}=\mathrm{CH}_{3}$

Shema 26 - Nastanak laktonskog produkta nakon reakcije QM-a s fosfatom ${ }^{89}$

Scheme 26 - Formation of lactone product in the reaction of QM with phosphate ${ }^{89}$ 
QM reagiraju s purinskim nukleobazama (dA 139 i dG 140) preko egzocikličkih amino-skupina na položajima C6, odnosno C2. . $^{7,91 a, 92} \mathrm{dC} \mathbf{1 4 1}$ reagira preko dušika N1 u prstenu, dok dT ne daje adukte s QM-om jer je vrlo slab nukleofil. ${ }^{91 b} \cup$ kompeticijskim eksperimentima s deoksinukleozidima utvrđeno je da je reakcija s citozinom više od 10 puta brža od reakcije s adenozinom ili gvaninom. Reaktivnost nukleobaza koje su dio DNA molekule znatno je manja, a ponajviše je smanjena reaktivnost citozina (>3600 puta), dok reaktivnost gvanina ovdje dolazi do izražaja, pa on u dvostrukoj zavojnici DNA postaje glavna meta za reakcije s QM-om, ponajprije na egzocikličkoj amino-skupini na položaju C2. ${ }^{92 b, 70 b}$

Reakciju fotodeaminacije kod bifenilnog derivata $\mathbf{8 4}$ primijenili su Zhou i sur. te su pokazali da ima sposobnost križnog povezivanja lanaca u DNA. ${ }^{46}$

Osim reakcije fotodehidratacije $\mathrm{u}$ derivatu BINOL-a 60, ${ }^{11 a}$ Freccero $i$ sur. studirali su i reakciju fotodeaminacije u bis-soli 87. ${ }^{11 \mathrm{~b}}$ Pokazali su da ozračivanje u prisutnosti plazmidne DNA dovodi do križnog povezivanja njezinih lanaca (shema 27), a to su potvrdili elektroforezom (križno povezana DNA ima različitu elektroforetsku pokretljivost u odnosu na normalnu DNA).
Freccero $i$ sur. zatim su razvili cijeli niz derivata, koji su po svojoj strukturi konjugati BINOL-a i aminokiselina: prolina, alanina, valina i lizina te u reakciji fotodeaminacije daju QM (slika 16). ${ }^{11 a}$ Spojevi 87 i $\mathbf{1 4 8 b}$ u koncentracijama $1-2 \mu \mathrm{mol} \mathrm{dm}^{-3}$ uzrokuju križno povezivanje DNA nakon ozračivanja. Zanimljivo je da nije primijećena razlika u sposobnosti križnog povezivanja između različitih enantiomera (87) ili dijastereomera (npr. 147b i 148b). Iz tog razloga spojevi 149 a-c biološki su testirani u obliku racemičnih smjesa. Spoj 149b križno povezuje DNA u znatno manjim koncentracijama $\left(5 \mu \mathrm{mol} \mathrm{dm}^{-3}\right)$ nego spojevi 149a i 149c (40, odnosno $20 \mu \mathrm{mol} \mathrm{dm}^{-3}$ ).

Spojevi 149a-b su citotoksični u koncentracijama reda veličine $\mu \mathrm{mol} \mathrm{dm^{-3 }}$ i to nije pojačano ozračivanjem, dok je citotoksičnost spojeva $147 a$ i $148 a$ povećana za oko 800 - 900 puta nakon ozračivanja. Istraživana je fotoreaktivnost i biološka aktivnost derivata BINOL-a s 2,6-supstitucijom 150a-e. ${ }^{1 \mathrm{~d}}$ Spojevi 88 i 150a križno povezuju DNA pri ozračivanju u koncentracijama 0,3 odnosno $1,25 \mu \mathrm{mol} \mathrm{dm}{ }^{-3}$. Od derivata $\mathbf{1 5 0 b}-\mathbf{d}$ metilni ester 150c i hidrokloridna sol kiseline $\mathbf{1 5 0 b}$ citotoksični su nakon

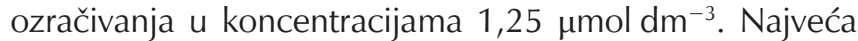
razlika između citotoksičnosti i fotocitotoksičnosti je primijećena kod najjednostavnijeg derivata $\mathbf{8 8}$.

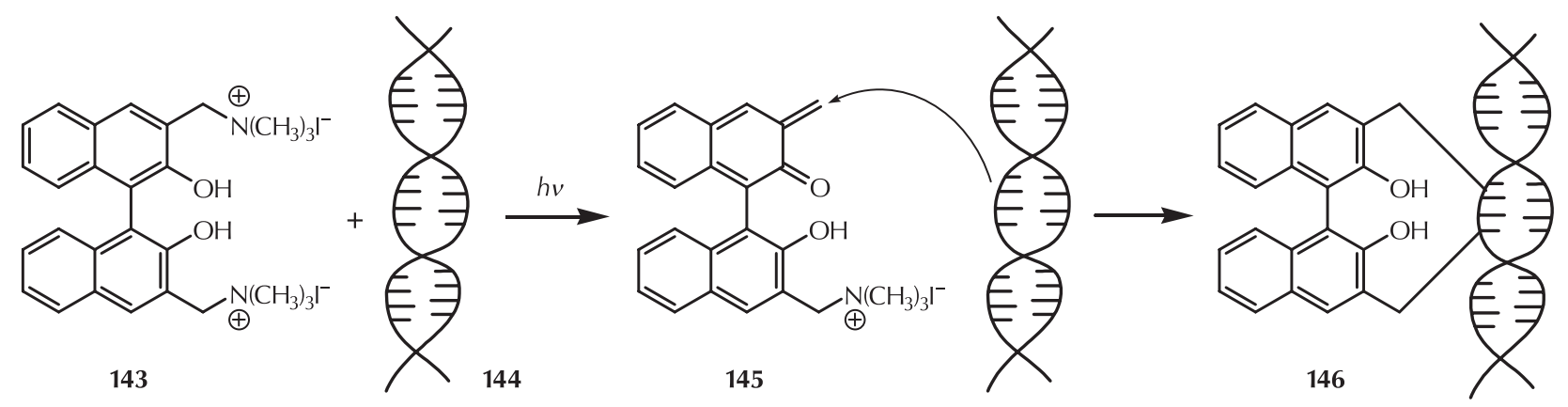

Shema 27 - Križno povezivanje DNA derivatom BINOL-a $\mathbf{1 4 3}{ }^{11 \mathrm{~b}}$

Scheme 27 - Cross-linking of DNA with BINOL derivative $143^{11 \mathrm{~b}}$<smiles>[R]Cc1cc2ccccc2c(-c2c(O)c(CC)cc3ccccc23)c1O</smiles>

$147 a-d$<smiles>[R]Cc1cc2ccccc2c(-c2c(O)c(C[R])cc3ccccc23)c1O</smiles>

$149 a-c$<smiles>[R]Cc1cc2ccccc2c(-c2c(O)c(C[R])cc3ccccc23)c1O</smiles>

$148 a-d$<smiles>[R]Cc1ccc2c(-c3c(O)ccc4cc(C[R])ccc34)c(O)ccc2c1</smiles>

$150 a-e$

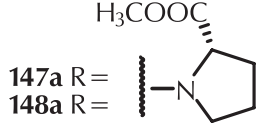

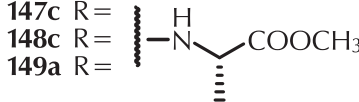

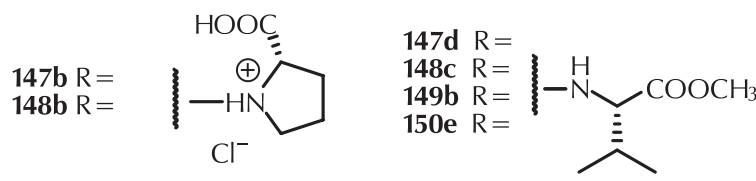<smiles>CC(C)N[C@@H](CCCC[NH3+])C(=O)O</smiles>

$150 a \mathrm{R}=\mathrm{OH}$

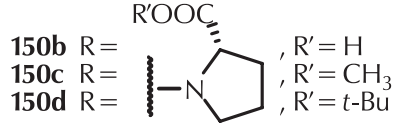

Slika 16 - Prekursori BINOL-nih QM-a ${ }^{11 a}$

Fig. 16 - Precursors of BINOL-type QMs ${ }^{11 a}$ 
S obzirom na dobru selektivnost porfirina prema stanicama raka i antitumorskoj aktivnosti nakon pobude apsorpcijom zračenja, Zhou i sur. pripravili su derivat porfirina 151 (slika 17), koji ozračivanjem nakon fotodeaminacije može dati QM. ${ }^{93}$ Utvrdili su da prilikom ozračivanja u prisutnosti superzavijene pBR322 DNA dolazi do pucanja lanaca DNA, što može biti uzrokovano reakcijom s QM-om ili generiranjem singletnog kisika, no prisutnost QM-a nije dokazana niti kemijskim rekcijama s nukleofilima, niti LFP-om.

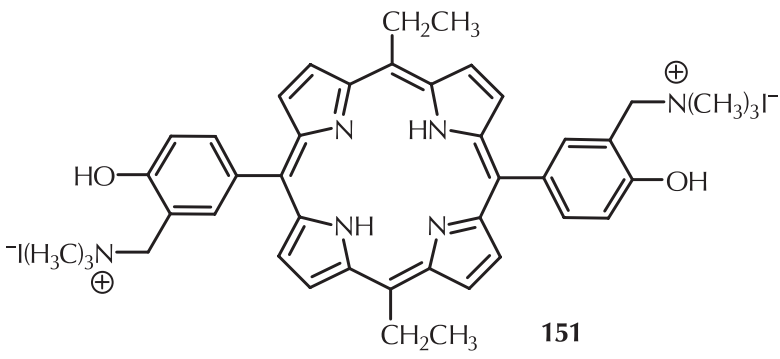

Slika 17 - Porfirinski prekursor QM-a

Fig. 17 - Porphyrine precursor of QM

Basarić je sa svojim suradnicima istraživao biološku aktivnost QM-a fotogeneriranih iz bifenilne serije spojeva $152-155$ (slika 18). ${ }^{7}$

Antiproliferativna aktivnost spojeva 152-155 testirana je na tri čovječje stanične linije karcinoma: HCT 116 (karcinom debelog crijeva), MCF-7 (karcinom dojke) i H 460 (karcinom pluća) s ozračivanjem i bez njega (300 nm, 3 dana, svaki dan po $1 \mathrm{~min}$ ). Dobivene su $\mathrm{IC}_{50}$ vrijednosti (koncentracija koja uzrokuje 50 \%-tnu inhibiciju rasta sta-
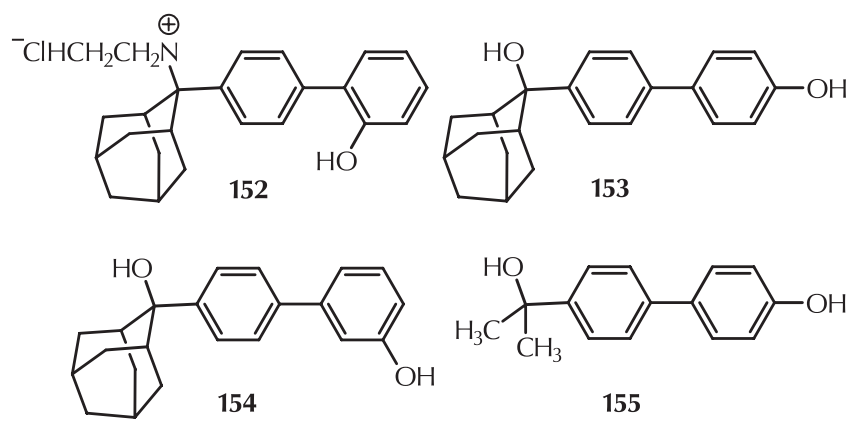

Slika 18 - Bifenilna serija spojeva, prekursora $\mathrm{QM}^{7}$ Fig. 18 - Biphenyl series of QM precursors ${ }^{7}$

nica) za svaki pojedini spoj (tablica 2). Najveće povećanje antiproliferativne aktivnosti pri ozračivanju nađeno je kod derivata 153, koji se pokazao selektivno citotoksičan za stanice karcinoma debelog crijeva (HCT 116). ${ }^{7}$

U nastavku istraživanja proučavana je fotokemijska reaktivnost i biološka aktivnost derivata naftola 156-160, koji nakon fotopobude daju odgovarajuće QM 161-164 (slika 19). ${ }^{8}$ Spojevi sadrže veliku adamantansku jedinicu, za koju se već prije pokazalo da stabilizira QM i produljuje njihovo vrijeme života, te time povećava njihovu selektivnost u reakcijama. ${ }^{5}$ Prijelazom s fenila ${ }^{5}$ i bifenila ${ }^{7}$ na naftalenski kromofor postignuto je da prekursori QM-a apsorbiraju valne duljine zračenja $\geq 300 \mathrm{~nm}$, što je primjerenije za primjenu u biološkim sustavima, za razliku od štetnog UV-zračenja.

Zanimljivo je napomenuti da su iz serije naftalenskih prekursora dobivena dva stabilna QM-a 165 i 166 (slika 20), koji ne reagiraju s nukleofilima.

Tablica 2 - IC $\mathrm{C}_{50}$ vrijednosti ${ }^{7}$ za spojeve 152-155

Table $2-\mathrm{IC}_{50}$ values $^{7}$ for compounds $\mathbf{1 5 2}-\mathbf{1 5 5}$

\begin{tabular}{|c|c|c|c|c|c|c|}
\hline \multirow{4}{*}{$\begin{array}{c}\text { Prekursor QM-a } \\
\text { QM precursor }\end{array}$} & \multicolumn{6}{|c|}{$\begin{array}{c}\text { Stanične linije } \\
\text { Cell lines }\end{array}$} \\
\hline & \multicolumn{2}{|c|}{ НСТ 116} & \multicolumn{2}{|c|}{ MCF-7 } & \multicolumn{2}{|c|}{ H 460} \\
\hline & \multicolumn{6}{|c|}{$\mathrm{IC}_{50} / \mu \mathrm{mol} \mathrm{dm}^{-3}$} \\
\hline & $\begin{array}{c}\text { neozračeno } \\
\text { non-irradiated }\end{array}$ & $\begin{array}{l}\text { ozračeno }^{\mathrm{a}} \\
\text { irradiated }^{\mathrm{a}}\end{array}$ & $\begin{array}{c}\text { neozračeno } \\
\text { non-irradiated }\end{array}$ & $\begin{array}{l}\text { ozračeno }^{b} \\
\text { irradiated }^{b}\end{array}$ & $\begin{array}{c}\text { neozračeno } \\
\text { non-irradiated }\end{array}$ & $\begin{array}{l}\text { ozračeno }^{\mathrm{a}} \\
\text { irradiated }^{\mathrm{a}}\end{array}$ \\
\hline 152 & $11 \pm 0,7$ & $14 \pm 3$ & $11 \pm 2$ & $15 \pm 4$ & $4 \pm 1$ & $12 \pm 0,4$ \\
\hline 153 & $>100$ & $9 \pm 1$ & $>100$ & $>100$ & $>100$ & $>100$ \\
\hline 154 & $36 \pm 5$ & $26 \pm 5$ & $29 \pm 13$ & $19 \pm 5$ & $29 \pm 3$ & $25 \pm 3$ \\
\hline 155 & $68 \pm 7$ & $64 \pm 3$ & $50 \pm 3$ & $13 \pm 4$ & $20 \pm 2$ & $16 \pm 3$ \\
\hline
\end{tabular}

${ }^{a}$ Ozračeno $3 \times 1$ min na $300 \mathrm{~nm}$ sa 6 lampi.

Irradiated for $3 \times 1 \mathrm{~min}$ at $300 \mathrm{~nm}$ with 6 lamps. 
<smiles>Oc1cc2ccccc2cc1C(O)(C1CC2CCC1C2)C(F)(F)F</smiles><smiles>O=C1C=c2ccccc2=CC1=C1C2CC3CC(C2)CC1C3</smiles><smiles>Oc1ccc2cc(C(O)(c3cccc(Br)c3)C3CC4CCC3C4)ccc2c1</smiles><smiles>CNC(C)(c1ccc2cc(O)ccc2c1)C1CC2CCC1C2</smiles><smiles>O=C1C=Cc2cc(=C3C4CC5CC(C4)CC3C5)ccc2=C1</smiles><smiles></smiles><smiles>[O-]c1ccc2ccc(C3C4CC5CC(C4)CC3C5)cc2c1</smiles>
159<smiles>Oc1cccc2c(C3(O)CC4CCC3C4)cccc12</smiles><smiles>O=C1C=CC=c2c1cccc2=C1C2CC3CC(C3)CC1C2</smiles>

Slika 19 - Naftalenski prekursori QM-a ${ }^{8}$ Fig. 19 - Naphthalene precursors of $\mathrm{QM}^{8}$<smiles>O=C1C=CC(=C2C3CC4CC(C3)CC2C4)c2ccccc21</smiles><smiles>O=C1C=Cc2ccccc2C1=C1C2CC3CC(C2)CC1C3</smiles>

Slika 20 - Stabilni naftalenski $\mathrm{QM}^{8}$ Fig. 20 - Stable naphthalene QMs ${ }^{8}$

LFP-om (u $\mathrm{CH}_{3} \mathrm{CN}-\mathrm{H}_{2} \mathrm{O} 1$ : 1) su detektirani QM 161 i 164 te su im određena vremena života. Radi se o dugoživućim QM-ima s vremenima života u milisekundama $(0,2 \mathrm{~ms}$ za QM 161, odnosno 0,9 ms za QM 164). Određene su i konstante brzine reakcije tih QM-a s nukleofilima. Osim fotokemijske reaktivnosti i studija LFP, na ovoj seriji spojeva napravljeno je i antiproliferativno ispitivanje, čiji su rezultati prikazani u tablici 3 .

Pokazano je da svi spojevi osim derivata 156 pokazuju antiproliferativnu aktivnost čak i bez ozračivanja, dok su sta- bilni QM 165 i 166 aktivni već i u oko 10 puta manjim koncentracijama. Razlika citotoksičnosti za ozračeni $(300 \mathrm{~nm}) \mathrm{i}$ neozračeni uzorak najznačajnija je kod spoja 156, ali samo kod stanične linije MCF-7 $\left(\mathrm{IC}_{50}=5 \mu \mathrm{mol} \mathrm{dm}{ }^{-3}\right)$, gdje uz ozračivanje pokazuje više od 20 puta veću antiproliferativnu aktivnost. Povećana antiproliferativna aktivnost uslijed ozračivanja vjerojatno je uzrokovana fotokemijskim generiranjem QM 161, što je u skladu s vrlo visokim kvantnim prinosom fotodehidratacije spoja $156(\phi=0,70)$.

U nastavku istraživanja povećan je kromofor ugradnjom još jednog fenilnog prstena, kao logičan nastavak istraživanja provedenih na bifenilnim derivatima. Iz bifenilnih derivata su reakcijom fotodehidratacije generirani QM s visokim kvantnim prinosima, a na humanim staničnim linijama karcinoma opaženo je povećanje antiproliferativnog učinka uz ozračivanje. ${ }^{7}$ Nadalje je pripravljena serija naftilfenola 167-172 u kojima je naftalenski prsten razmaknica između $p$-fenola i $\mathrm{OH}$ skupine na benzilnom položaju (slika 21). ${ }^{9}$ Ispitana je fotokemijska reaktivnost molekula u reakcijama fotosolvolize i učinkovitost fotokemijskog nastajanja QM-a, čiji je cilj bio pronaći optimalan položaj supstitucije na naftalenskom kromoforu za najveću učinkovitost reakcije dehidratacije. Pokazalo se da kod 2,6-supstituiranog derivata $\mathbf{1 7 1}$ dolazi do najučinkovitijeg generiranja QM $(\phi=0,25 \pm 0,02)$. 
Tablica $3-\mathrm{IC}_{50}$ vrijednosti ${ }^{8}$

Table $3-\mathrm{IC}_{50}$ values ${ }^{8}$

\begin{tabular}{|c|c|c|c|c|c|c|}
\hline \multirow{4}{*}{$\begin{array}{c}\text { Prekursor QM-a } \\
\text { QM precursor }\end{array}$} & \multicolumn{6}{|c|}{$\begin{array}{c}\text { Stanične linije } \\
\text { Cell lines }\end{array}$} \\
\hline & \multicolumn{2}{|c|}{ НСТ 116} & \multicolumn{2}{|c|}{ MCF-7 } & \multicolumn{2}{|c|}{$\mathrm{H} 460$} \\
\hline & \multicolumn{6}{|c|}{$\mathrm{IC}_{50} / \mu \mathrm{mol} \mathrm{dm}^{-3}$} \\
\hline & $\begin{array}{c}\text { neozračeno } \\
\text { non-irradiated }\end{array}$ & $\begin{array}{l}\text { ozračeno }^{\mathrm{a}} \\
\text { irradiated }^{\mathrm{a}}\end{array}$ & $\begin{array}{c}\text { neozračeno } \\
\text { non-irradiated }\end{array}$ & $\begin{array}{l}\text { ozračeno }^{\mathrm{a}} \\
\text { irradiated }^{\mathrm{a}}\end{array}$ & $\begin{array}{c}\text { neozračeno } \\
\text { non-irradiated }\end{array}$ & $\begin{array}{l}\text { ozračeno }^{\mathrm{a}} \\
\text { irradiated }^{\mathrm{a}}\end{array}$ \\
\hline 156 & $\geq 100$ & $\geq 100$ & $\geq 100$ & $5 \pm 1$ & $\geq 100$ & $\geq 100$ \\
\hline 157 & $17 \pm 3$ & $16 \pm 2$ & $19 \pm 3$ & $16 \pm 3$ & $19 \pm 1$ & $18 \pm 2$ \\
\hline 158 & $11 \pm 0,1$ & $12 \pm 1$ & $12 \pm 2$ & $11 \pm 1$ & $10 \pm 1$ & $6 \pm 5$ \\
\hline 159 & $39 \pm 1$ & $34 \pm 1$ & $23 \pm 6$ & $18 \pm 2$ & $45 \pm 10$ & $29 \pm 12$ \\
\hline 160 & $36 \pm 25$ & $45 \pm 35$ & $39 \pm 16$ & $24 \pm 4$ & $25 \pm 1$ & $20 \pm 8$ \\
\hline 165 & $2,0 \pm 0,1$ & - & $1,0 \pm 0,4$ & - & $2,0 \pm 0,2$ & - \\
\hline 166 & $2,0 \pm 0,1$ & - & $3,0 \pm 0,1$ & - & $2,0 \pm 0,1$ & - \\
\hline $\begin{array}{c}\text { trioksalen }^{\mathrm{b}} \\
\text { trioxsalene }^{\mathrm{b}}\end{array}$ & $19 \pm 2$ & $0,2 \pm 0,02$ & $34 \pm 6$ & $0,24 \pm 0,1$ & $\geq 100$ & $0,1 \pm 0,1$ \\
\hline
\end{tabular}

${ }^{a}$ Ozračeno $3 \times 1$ min na 300 nm sa 6 lampi. U izračunu $I_{50}$ vrijednosti uspoređen je uzorak tretiranih i ozračenih staničnih linija s netretiranim i ozračenim stanicama (kontrola), pa primijećenih 25 \% inhibicije rasta uzrokovano zračenjem na 300 nm ne utječe na ovdje prikazane rezultate.

Irradiated for $3 \times 1 \mathrm{~min}$ at $300 \mathrm{~nm}$ with 6 lamps. In the calculation of $\mathrm{IC}_{50}$ values, the sample of treated and irradiated cell lines was compared with the sample of untreated and irradiated cell lines (control). Therefore, the observed $25 \%$ of growth inhibition caused by irradiation at 300 nm have no effect on here presented results.

b Trioksalen, IUPAC naziv: 2,5,9-trimetil-7H-furo[3,2-g]kromen-7-on.

Trioxsalene, IUPAC name: 2,5,9-trimethyl-7H-furo[3,2-g]chromen-7-on.

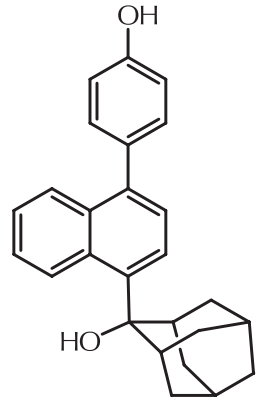

167<smiles>Oc1ccc(-c2ccc(C(O)(c3ccccc3)c3ccccc3)c3ccccc23)cc1</smiles>

168<smiles>Oc1ccc(-c2cccc3c(C4(O)C5CC6CC(C5)CC4C6)cccc23)cc1</smiles>

169<smiles>Oc1ccc(-c2cccc3c(C(O)(c4ccccc4)c4ccccc4)cccc23)cc1</smiles>

170<smiles>Oc1ccc(-c2ccc3cc(C4(O)C5CC6CC(C5)CC4C6)ccc3c2)cc1</smiles><smiles>Oc1ccc(-c2ccc3cc(C(O)(c4ccccc4)c4ccccc4)ccc3c2)cc1</smiles>

172

Slika 21 - Naftil-fenolni prekursori QM-a ${ }^{9}$

Fig. 21 - Naphthyl-phenol precursors of $\mathrm{QMs}^{9}$

Međutim spojevi 167-172 nisu pokazali povećanje antiproliferativne aktivnosti uz ozračivanje.

Daljnje povećanje kromofora postignuto je uvođenjem antracenske jedinice. Tako je pripravljen prekursor QM 173, ${ }^{10}$ čija je valna duljina apsorpcijskog maksimuma na više od 350 nm, što je bio konačni cilj zbog potencijalne primjene u biološkim sustavima, uz izbjegavanje za stanice štetnog UV-zračenja. Derivati antracena zanimljivi su i stoga što je za antracen poznato da se može interkalirati između parova baza u DNA, ${ }^{94}$ za što je pretpostavljeno da bi moglo biti korisno svojstvo s obzirom na to da dovodi reagens na mjesto gdje se treba odviti fotokemijska reakcija. Sličan pristup uspješno su primijenili Rokita $i$ sur. ${ }^{70 d}$ Utvrđeno je da kod spoja 173 nakon pobuđivanja dolazi do generiranja QM-a 174 koji je u kiselo-baznoj ravnoteži s kationom 175. Ozračivanjem u prisutnosti nukleofila dobiveni su odgovarajući adukti $\mathbf{1 7 6}$. 


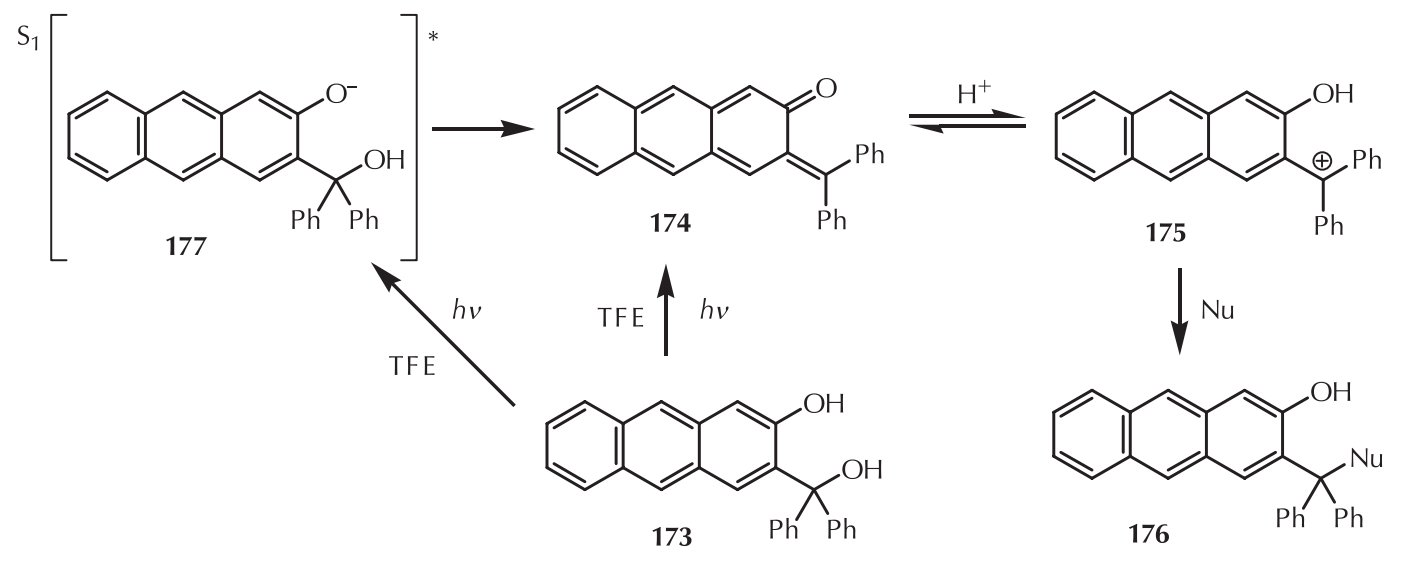

Shema 28 - Fotokemija spoja $\mathbf{1 7 3} \mathbf{3}^{10}$

Scheme 28 - Photochemistry of compound $173^{10}$

Spoj 173 je uz ozračivanje pokazao 5 - 10 puta veću antiproliferativnu aktivnost $u$ odnosu na neozračene stanice (tablica 4). Do povećanja antiproliferativne aktivnosti dolazi čak i kad je upotrijebljeno svjetlo valne duljine koja pada u vidljivi dio spektra (420 nm), što znači da spoj 173 i slični derivati imaju velik potencijal za razvoj novih fotokemoterapeutika.

Tablica $4-\mathrm{IC}_{50}$ vrijednosti za spoj $\mathbf{1 7 3 ^ { 1 0 }}$

Table $4-\mathrm{IC}_{50}$ values for compound $\mathbf{1 7 3} \mathbf{1 0}^{10}$

\begin{tabular}{|c|c|c|c|}
\hline \multirow{2}{*}{$\begin{array}{l}\text { Stanične linije } \\
\text { Cell lines }\end{array}$} & \multicolumn{3}{|c|}{$\mathrm{IC}_{50} / \mu \mathrm{mol} \mathrm{dm}^{-3}$} \\
\hline & $\begin{array}{c}\text { neozračeno } \\
\text { non-irradiated }\end{array}$ & $\begin{array}{c}350 \mathrm{~nm} \\
3 \times 5 \mathrm{~min}\end{array}$ & $\begin{array}{c}420 \mathrm{~nm} \\
3 \times 15 \mathrm{~min}\end{array}$ \\
\hline НСТ 116 & $21 \pm 0,3$ & $2 \pm 0,4$ & $2 \pm 0,4$ \\
\hline MCF-7 & $20 \pm 0,5$ & $4 \pm 3$ & $2 \pm 0,1$ \\
\hline H 460 & $19 \pm 1$ & $3 \pm 1$ & $2 \pm 0,2$ \\
\hline
\end{tabular}

\section{Zaključak}

Fotokemijske metode generiranja QM-a (kinon-metidi, naziv po IUPAC-u: kinometani) pružaju mogućnost prostorne i vremenske kontrole nad njihovim stvaranjem, a ujedno su i vrlo blage jer ne zahtijevaju nikakav drugi reagens osim fotona. Metode vremenski razlučene spektroskopije omogućuju studij reaktivnosti QM-a (čak i na femtosekundnoj skali), što je vrlo važno jer omogućuje korelaciju strukture i reaktivnosti, a time i dizajn novih prekursora QM-a, s poboljšanim svojstvima koja su zanimljiva. Najčešća metoda generiranja QM-a je reakcija fotodeaminacije. Međutim, reakcija fotodehidratacije mogla bi biti primjenjivija u biološkim sustavima, ponajprije zbog njezine reverzibilnosti. Kod takvih derivata nukleofilni napad vode na QM regenerira prekursor QM-a, pa to ne dovodi do propadanja aktivnog agensa. Jedan od najvažnijih ciljeva kod priprave prekursora QM-a koji bi bili upotrebljivi kao lijekovi je pomicanje valne duljine apsorpcije prekursora na 650 nm, jer takvo svjetlo najbolje prodire kroz tkivo. To bi omogućilo generiranje QM-a ne samo in vitro nego in vivo - u tkivima živih organizama, čime se otvaraju nove mogućnosti za razvoj novih lijekova i konkretnu primjenu u liječenju malignih bolesti.

\section{Popis kratica i simbola \\ List of abbreviations and symbols}

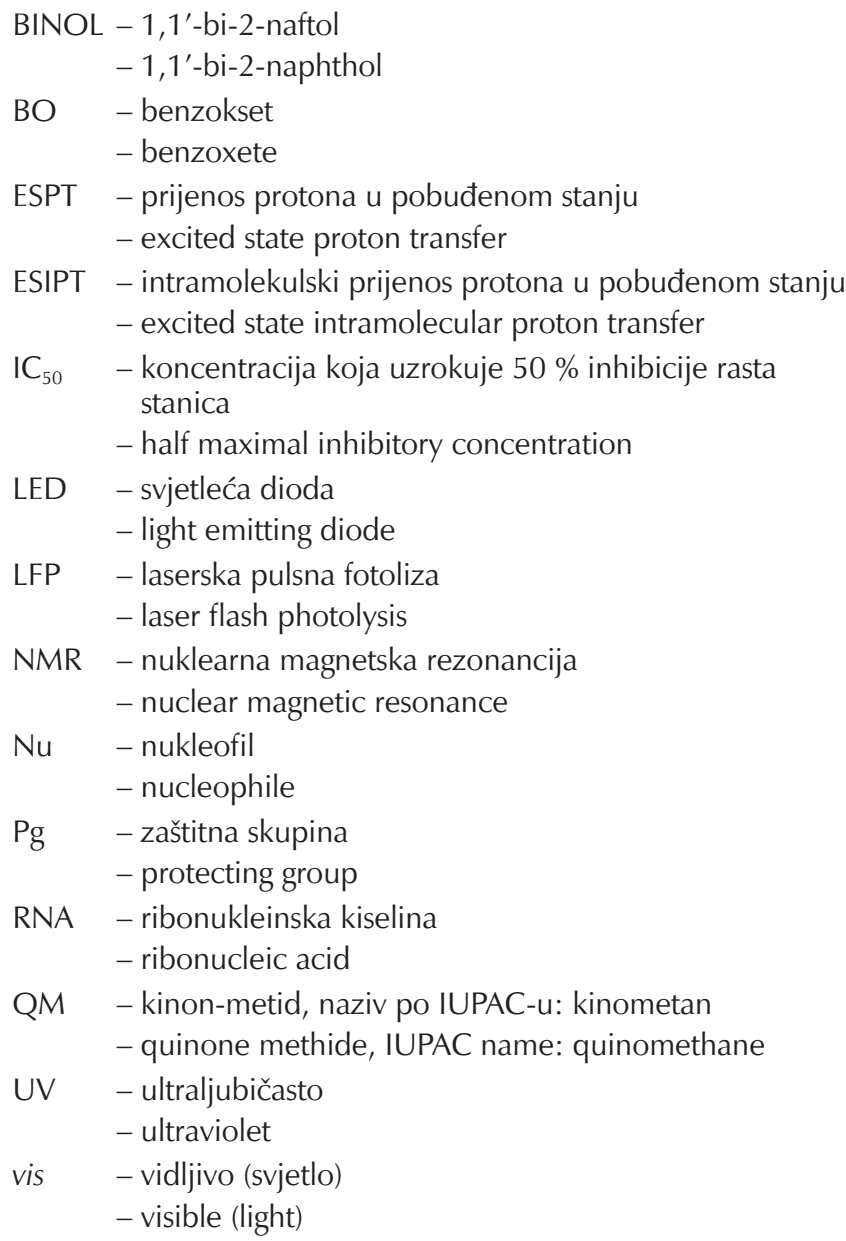




\section{Literatura}

\section{References}

1. M. Lukeman, Quinone Methides, S. E. Rokita (urednik), John Wiley\&Sons, Hoboken, 2009, 1. poglavlje.

2. (a) R. W. Van De Water, T. R. R. Pettus, o-Quinone methides: intermediates underdeveloped and underutilized in organic synthesis, Tetrahedron 58 (2002) 5367-5405, doi: https:// doi.org/10.1016/S0040-4020(02)00496-9; (b) M. Shankar Singh, A. Nagaraju, N. Anand, S. Chowdhury, ortho-Quinone methide (o-QM): a highly reactive, ephemeral and versatile intermediate in organic synthesis, RSC Adv. 4 (2014) 5592455959, doi: https://doi.org/10.1039/C4RA11444B.

3.Đ. Škalamera, T. Śumanovac Ramljak, A. Husak, Kinon-metidi (I. dio): Reaktivni međuprodukti u kemiji fenola i njihova primjena u organskoj sintezi, Kem. Ind. 66 (7-8) (2017) 353372, doi: https://doi.org/10.15255/KUI.2016.029.

4. N. Basarić, K. Mlinarić-Majerski, M. Kralj, Quinone Methides: Photochemical Generation and its Application in Biomedicine, Curr. Org. Chem. 18 (2014) 3-18, doi: https://doi.org/1 $0.2174 / 138527281801140121122330$.

5. N. Basarić, I. Žabčić, K. Mlinarić-Majerski, P. Wan, Photochemical Formation and Chemistry of Long-Lived Adamantylidene-Quinone Methides and 2-Adamantyl Cations, J. Org. Chem. 75 (2010) 102-116, doi: https://doi.org/10.1021/ jo902004n.

6. N. Basarić, N. Cindro, Y. Hou, I. Žabčić, K. Mlinarić -Majerski, P. Wan, Competing photodehydration and excited-state intramolecular proton transfer (ESIPT) in adamantyl derivatives of 2-phenylphenols, Can. J. Chem. 89 (2011) 221-234, doi: https://doi.org/10.1139/V10-102.

7. (a) N. Basarić, N. Cindro, D. Bobinac, K. Mlinarić-Majerski, L. Uzelac, M. Kralj, P. Wan, Sterically congested quinone methides in photodehydration reactions of 4-hydroxybiphenyl derivatives and investigation of their antiproliferative activity, Photochem. Photobiol. Sci. 10 (2011) 1910-1925, doi: https://doi.org/10.1039/c1pp05182b; (b) N. Basarić, N. Cindro, D. Bobinac, L. Uzelac, K. Mlinarić-Majerski, M. Kralj, P. Wan, Zwitterionic biphenyl quinone methides in photodehydration reactions of 3-hydroxybiphenyl derivatives: laser flash photolysis and antiproliferation study, Photochem. Photobiol. Sci. 11 (2012) 381-396, doi: https://doi.org/10.1039/ c1pp05338h.

8.J. Veljković, L. Uzelac, K. Molčanov, K. Mlinarić-Majerski, M. Kralj, P. Wan, N. Basarić, Sterically Congested Adamantylnaphthalene Quinone Methides, J. Org. Chem. 77 (2012) 4596-4610, doi: https://doi.org/10.1021/jo3002479.

9. Đ. Škalamera, K. Mlinarić-Majerski, L. Uzelac, M. Kralj, P. Wan, N. Basarić, Photosolvolysis of bulky (4-hydroxyphenyl)-naphthalene derivatives, Photochem. Photobiol. Sci. 12 (2013) 2043-2056, doi: https://doi.org/10.1039/c0xx00000x.

10. Đ. Škalamera, K. Mlinarić-Majerski, I. Martin-Kleiner, M. Kralj, P. Wan, N. Basarić, Near-Visible Light Generation of a Quinone Methide from 3-Hydroxymethyl-2-anthrol, J. Org. Chem. 79 (2014) 4390-4397, doi: https://doi.org/10.1021/ jo500290y.

11. (a) F. Doria, S. N. Richter, M. Nadai, S. Colloredo-Mels, M. Palumbo, M. Freccero, BINOL-Amino Acid Conjugates as Triggerable Carriers of DNA-Targeted Potent Photocytotoxic Agents, J. Med. Chem. 50 (2007) 6570-6579, doi: https:// doi.org/10.1021/jm070828x; (b) S. N. Richter, S. Maggi, S. Colloredo Mels, M. Palumbo, M. Freccero, Binol Quinone Methides as Bisalkylating and DNA Cross-Linking Agents, J. Am. Chem. Soc. 126 (2004) 13973-13979, doi: https:// doi.org/10.1021/ja047655a; (c) D. Verga, M. Nadai, F. Doria, C. Percivalle, M. Di Antonio, M. Palumbo, S. N. Richter, M. Freccero, Photogeneration and Reactivity of Naphthoquinone Methides as Purine Selective DNA Alkylating Agents, J. Am. Chem. Soc. 132 (2010) 14625-14637, doi: https://doi. org/10.1021/ja1063857.
12. (a) H. E. Zimmerman, V. R. Sandel, Mechanistic Organic Photochemistry. II. 1,2 Solvolytic Photochemical Reactions, J. Am. Chem. Soc. 85 (1963) 915-922, doi: https://doi.org/10.1021/ ja00890a019; (b) H. E. Zimmerman, The Meta Effect in Organic Photochemistry: Mechanistic and Exploratory Organic Photochemistry, J. Am. Chem. Soc. 117 (1995) 8988-8991, doi: https://doi.org/10.1021/ja00140a014.

13. (a) M. Fagnoni, A. Albini, Arylation Reactions: The Photo-SN1 Path via Phenyl Cation as an Alternative to Metal Catalysis, Acc. Chem. Res. 38 (2005) 713-721, doi: https://doi.org/10.1021/ ar0402356; (b) M. De Carolis, S. Protti, M. Fagnoni, A. Albini, Metal-Free Cross-Coupling Reactions of Aryl Sulfonates and Phosphates through Photoheterolysis of Aryl-Oxygen Bonds, Angew. Chem., Int. Ed. 44 (2005) 1232-1236, doi: https:// doi.org/10.1002/anie.200461444; (c) M. Slegt, S. Hermen, H. S. Overkleeft, G. Lodder, Fingerprints of Singlet and Triplet Phenyl Cations, Eur. J. Org. Chem. (2007) 5364-5375, doi: https://doi.org/10.1002/ejoc.200700339; (d) V. Dichiarante, M. Fagnoni, Aryl Cation Chemistry as an Emerging Versatile Tool for Metal-Free Arylations, Synlett (2008) 787-800, doi: https://doi.org/10.1055/s-2008-1042933; (e) S. Lazzaroni, D. Dondi, M. Fagnoni, A. Albini, Geometry and Energy of Substituted Phenyl Cations, J. Org. Chem. 73 (2008) 206-211, doi: https://doi.org/10.1021/jo7020218; (f) V. Dichiarante, M. Fagnoni, A. Albini, Using Phenyl Cations as Probes for Establishing Electrophilicity-Nucleophilicity Relations, J. Org. Chem. 73 (2008) 1282-1289, doi: https://doi.org/10.1021/ jo7019509; (g) S. Lazzaroni, S. Protti, M. Fagnoni, A. Albini, Photoinduced Three-Component Reaction: A Convenient Access to 3-Arylacetals or 3-Arylketals, Org. Lett. 11 (2009) 349-352, doi: https://doi.org/10.1021/ol802560t; h) V. Dichiarante, M. Fagnoni, A. Albini, Eco-friendly hydrodehalogenation of electron-rich aryl chlorides and fluorides by photochemical reaction, Green Chem. 11 (2009) 942-945, doi: https://doi.org/10.1039/B904897A; (i) S. Lazzaroni, D. Dondi, A. Albini, Selectivity in the reaction of triplet phenyl cations, J. Org. Chem. 75 (2010) 315-323, doi: https://doi. org/10.1021/jo9017974; (j) M. Terpolilli, D. Merli, S. Protti, V. Dichiarante, M. Fagnoni A. Albini, Cationic and radical intermediates in the acid photorelease from aryl sulfonates and phosphates, Photochem. Photobiol. Sci. 10 (2011) 123-127, doi: https://doi.org/10.1039/COPP00284D.

14. G. Grabner, C. Richard, G. Köhler, Formation and Reactivity of 4-Oxocyclohexa-2,5-dienylidene in the Photolysis of 4-Chlorophenol in Aqueous Solution at Ambient Temperature, J. Am. Chem. Soc. 116 (1994) 11470-11480, doi: https://doi. org/10.1021/ja00104a029.

15. P. J. Kropp, Photobehavior of alkyl halides in solution: radical, carbocation, and carbene intermediates, Acc. Chem. Res. 17 (1984) 131-137, doi: https://doi.org/10.1021/ar00100a003.

16. C. S. Rajesh, R. S. Givens, J. Wirz, Kinetics and Mechanism of Phosphate Photorelease from Benzoin Diethyl Phosphate: Evidence for Adiabatic Fission to an $\alpha$-Keto Cation in the Triplet State, J. Am. Chem. Soc. 122 (2000) 611-618, doi: https://doi.org/10.1021/ja993070i.

17. O. L. Chapman, C. L. Mclntosh, Photochemical decarbonylation of unsaturated lactones and carbonates, J. Chem. Soc. D: Chem. Commun. (1971) 383-384, doi: https://doi. org/10.1039/C29710000383.

18. A. Padwa, G. A. Lee, Photochemical transformations of 2,2-disubstituted chromenes, J. Chem. Soc. Chem. Commun. (1972) 795-796, doi: https://doi.org/10.1039/ C39720000795.

19. (a) P. Wang, H. Hu, Y. Wang, Novel photolabile protecting group for carbonyl compounds, Org. Lett. 9 (2007) 15331535, doi: https://doi.org/10.1021/ol070346f; (b) P. Wang, Y. Wang, H. Hu, C. Spencer, X. Liang, L. Pan, Sequential removal of photolabile protecting groups for carbonyls with controlled wavelength, J. Org. Chem. 73 (2008) 6152-6157, doi: https://doi.org/10.1021/jo8008275; (c) H. Yang, F. Mu, 
P. Wang, Oxidation with a photolabile carbonyl protecting group, J. Org. Chem. 76 (2011) 8955-8961, doi: https://doi. org/10.1021/jo201671v.

20. J.-H. Kim, F. Huang, M. Ly, R. J. Linhardt, Stereoselective synthesis of a C-linked neuraminic acid disaccharide: potential building block for the synthesis of C-analogues of polysialic acids, J. Org. Chem. 73 (2008) 9497-9500, doi: https://doi. org/10.1021/jo801946y.

21. J. F. Ireland, P. A. H. Wyatt, Acid-Base Properties of Electronically Excited States of Organic Molecules, Adv. Phys. Org. Chem. 12 (1976) 131-221, doi: https://doi.org/10.1016/ S0065-3160(08)60331-7.

22. N. Agmon, Elementary steps in excited-state proton transfer, J. Phys. Chem. A 109 (2005) 13-35, doi: https://doi. org/10.1021/jp047465m.

23. L. M. Tolbert, K. Solntsev, Excited-State Proton Transfer: From Constrained Systems to "Super" Photoacids to Superfast Proton Transfer, Acc. Chem. Res. 35 (2002) 19-27, doi: https:// doi.org/10.1021/ar990109f.

24. M. Kasha, Proton-transfer spectroscopy. Perturbation of the tautomerization potential, J. Chem. Soc., Faraday Trans. 282 (1986) 2379-2392, doi: https://doi.org/10.1039/ F29868202379.

25. (a) P. Seiler, J. Wirz, The photohydrolysis of eight isomeric trifluoromethylnaphthols, Tetrahedron Lett. 20 (1971) 16831686, doi: https://doi.org/10.1016/s0040-4039(01)87434-7; (b) P. Seiler, J. Wirz, Struktur und photochemische Reaktivität: Photohydrolyse von Trifluormethylsubstituierten Phenolen und Naphtholen, Helv. Chim. Acta 55 (1972) 2693-2712, doi: https://doi.org/10.1002/hlca.19720550802; (c) H. Huber, C. Pascual, J. Wirz, Notiz über die Kernresonanzspektren von trifluormethyl-substituierten Naphthalinderivaten, Helv. Chim. Acta 55 (1972) 2712-2716, doi: https://doi. org/10.1002/hlca.19720550802.

26. M. Gomberg, On triphenylmethyl. XXIII. Tautomerism of the hydroxy-triphenyl carbinols, J. Am. Chem. Soc. 35 (1913) 1035-1042, doi: https://doi.org/10.1021/ja02197a016.

27. T. W. Lewis, D. Y. Curtin, I. C. Paul, Thermal, photochemical, and photonucleated thermal dehydration of $p$-hydroxytriarylmethanols in solids. (3,5-Dimethyl-4-hydroxyphenyl) diphenylmethanol and (3,5-dibromo-4-hydroxyphenyl) diphenylmethanol. X-ray crystal structures of (4-hydroxyphenyl)diphenylmethanol and its 3,5-dimethyl derivative J. Am. Chem. Soc. 101 (1979) 5717-5725, doi: https://doi. org/10.1021/ja00513a043.

28. (a) S. Hamai, H. Kokubun, Photochromism of o-Hydroxytriphenylcarbinol, Z. Phys. Chem. 88 (1974) 211-214, doi: https://doi.org/10.1524/zpch.1974.88.1-4.211; (b) S. Hamai, H. Kokubun, Thermal Decay of the Colored Form in Photochromism of 2-Hydroxy-4-methoxytriphenylmethanol in n-Hexane, Bull. Chem. Soc. Jpn. 47 (1974) 2085-2088, doi: https://doi.org/10.1246/bcsj.47.2085.

29. (a) P. Wan, B. Chak, Structure-reactivity studies and catalytic effects in the photosolvolysis of methoxy-substituted benzyl alcohols, J. Chem. Soc., Perkin Trans 2 (1986) 1751-1756, doi: https://doi.org/10.1039/P29860001751; (b) L. Diao, C. Yang, P. Wan, Quinone Methide Intermediates from the Photolysis of Hydroxybenzyl Alcohols in Aqueous Solution, J. Am. Chem. Soc. 117 (1995) 5369-5370, doi: https://doi. org/10.1021/ja00124a024.

30. B. Baker, L. Diao, P. Wan, Intramolecular [4+2] cycloaddition of a photogenerated $o$-quinone methide in aqueous solution, J. Photochem. Photobiol. A. Chem. 104 (1997) 91-96, doi: https://doi.org/10.1016/S1010-6030(96)04535-2.

31. L. Diao, P. Wan, Chemistry of photogenerated $\alpha$-phenyl-substituted $o_{-}, \mathrm{m}-$, and $\mathrm{p}$-quinone methides from phenol derivatives in aqueous solution, Can. J. Chem. 86 (2008) 105-118, doi: https://doi.org/10.1139/v07-125.

32. Y. Shi, P. Wan, Solvolysis and ring closure of quinone methides photogenerated from biaryl systems, Can. J .Chem. 83 (2005) 1306-1323, doi: https://doi.org/10.1139/v05-138.

33. (a) D. Brousmiche, M. Xu, M. Lukeman, P. Wan, Photohydration and photosolvolysis of biphenyl alkenes and alcohols via biphenyl quinone methide-type intermediates and diarylmethyl carbocations, J. Am. Chem. Soc. 125 (2003) 12961-12970, doi: https://doi.org/10.1021/ja036808b; (b) M. Xu, M. Lukeman, P. Wan, Photogeneration and chemistry of biphenyl quinone methides from hydroxybiphenyl methanols, Photochem. Photobiol. 82 (2006) 50-56, doi: https:// doi.org/10.1562/2005-02-17-RA-444.

34. M. Xu, C. Z. Chen, P. Wan, Intramolecular charge transfer in photoexcited hydroxyterphenyls: Evidence for formation of terphenyl quinone methides in aqueous solution, J. Photochem. Photobiol. A: Chem. 198 (2008) 26-33, doi: https:// doi.org/10.1016/j.jphotochem.2008.02.012.

35. S. Arumugam, V. V. Popik, Photochemical Generation and the Reactivity of $o$-Naphthoquinone Methides in Aqueous Solutions, J. Am. Chem. Soc. 131 (2009) 11892-11899, doi: https://doi.org/10.1021/ja9031924.

36. A. Kulikov, S. Arumugam, V. V. Popik, Photolabile Protection of Alcohols, Phenols, and Carboxylic Acids with 3-Hydroxy-2-Naphthalenemethanol, J. Org. Chem. 73 (2008) 7611-7615, doi: https://doi.org/10.1021/jo801302m.

37. (a) S. Arumugam, V. V. Popik, Patterned Surface Derivatization Using Diels-Alder Photoclick Reaction, J. Am. Chem. Soc. 133 (2011) 15730-15736, doi: https://doi.org/10.1021/ ja205652m; (b) S. Arumugam, V. V. Popik, Attach, Remove, or Replace: Reversible Surface Functionalization Using Thiol-Quinone Methide Photoclick Chemistry, J. Am. Chem. Soc. 134 (2012) 8408-8411, doi: https://doi.org/10.1021/ ja302970x.

38. H. Meier, Benzoxetes and Benzothietes - Heterocyclic Analogues of Benzocyclobutene, Molecules 17 (2012) 15481570, doi: https://doi.org/10.3390/molecules17021548.

39. H. Tomioka, T. Matsushita, Benzoxetene. Direct Observation and Theoretical Studies Chem. Lett. (1997) 399-400, doi: https://doi.org/10.1246/cl.1997.399.

40. G. G.-H. Qiao, K. Lenghaus, D. H. Solomon, A. Reisinger, I. Bytheway, C. Wentrup, 4,6-Dimethyl-o-quinone Methide and 4,6-Dimethylbenzoxetem, J. Org. Chem. 63 (1998) 98069811, doi: https://doi.org/10.1021/jo981445x.

41. (a) Y. Chaing, A. J. Kresge, Y. Zhu, Kinetics and Mechanisms of Hydration of $O$-Quinone Methides in Aqueous Solution, J. Am. Chem. Soc. 122 (2000) 9854-9855, doi: https://doi. org/10.1021/ja001557h; (b) Y. Chaing, A. J. Kresge, Y. Zhu, Flash Photolytic Generation of ortho-Quinone Methide in Aqueous Solution and Study of Its Chemistry in that Medium, J. Am. Chem. Soc. 123 (2001) 8089-8094, doi: https:// doi.org/10.1021/ja010826g; (c) Y. Chaing, A. J. Kresge, Y. Zhu, Flash Photolytic Generation of o-Quinone $\alpha$-Phenylmethide and $o$-Quinone $\alpha$-(p-Anisyl)methide in Aqueous Solution and Investigation of Their Reactions in that Medium. Saturation of Acid-Catalyzed Hydration, J. Am. Chem. Soc. 124 (2002) 717-722, doi: https://doi.org/10.1021/ja0120375.

42. Y. Chaing, A. J. Kresge, Y. Zhu, Flash Photolytic Generation and Study of $p$-Quinone Methide in Aqueous Solution. An Estimate of Rate and Equilibrium Constants for Heterolysis of the Carbon-Bromine Bond in p-Hydroxybenzyl Bromide, J. Am. Chem. Soc. 124 (2002) 6349-6356, doi: https://doi. org/10.1021/ja020020w.

43. K. Nakatani, N. Higashida, I. Saito, Highly efficient photochemical generation of $O$-Quinone methide from Mannich bases of phenol derivatives, Tetrahedron Lett. 38 (1997) 5005-5008, doi: https://doi.org/10.1016/S0040-4039(97)01071-X.

44. J. Matsumoto, M. Ishizu, R.-I. Kawano, D. Hesaka, T. Shiragami, Y. Hayashi, T. Yamashita, M. Yasuda, Generation of quinone methide from aminomethyl(hydroxy)arenes precursors in aqueous solution, Tetrahedron 61 (2005) 5735-5740, doi: https://doi.org/10.1016/j.tet.2005.04.037. 
45. E. Modica, R. Zanaletti, M. Freccero, M. Mella, Alkylation of Amino Acids and Glutathione in Water by o-Quinone Methide. Reactivity and Selectivity, J. Org. Chem. 66 (2001) 41-52, doi: https://doi.org/10.1021/jo0006627.

46. P. Wang, R. Liu, X. Wu, H. Ma, X. Cao, P. Zhou, J. Zhang, X. Weng, X.-L. Zhang, A Potent, Water-Soluble and Photoinducible DNA Cross-Linking Agent, J. Am. Chem. Soc. 125 (2003) 1116-1117, doi: https://doi.org/10.1021/ja029040o.

47. D. Verga, S. N. Richter, M. Palumbo, R. Gandolfi, M. Freccero, Bipyridyl ligands as photoactivatable mono- and bis-alkylating agents capable of DNA cross-linking, Org. Biomol. Chem. 5 (2007) 233-235, doi: https://doi.org/10.1039/B616292D.

48. C. Percivalle, A. La Rosa, D. Verga, F. Doria, M. Mella, M. Palumbo, M. Di Antonio, M. Freccero, Quinone Methide Generation via Photoinduced Electron Transfer, J. Org. Chem. 76 (2011) 3096-3106, doi: https://doi.org/10.1021/jo102531f.

49. M. Di Antonio, F. Doria, S. N. Richter, C. Bertipaglia, M. Mella, C. Sissi, M. Palumbo, M. Freccero, Quinone Methides Tethered to Naphthalene Diimides as Selective G-Quadruplex Alkylating Agents, J. Am. Chem. Soc. 131 (2009) 1313213141, doi: https://doi.org/10.1021/ja904876q.

50. (a) M. Nadai, F. Doria, M. Di Antonio, G. Sattin, L. Germani, C. Percivalle, M. Palumbo, S. N. Richter, M. Freccero, Naphthalene diimide scaffolds with dual reversible and covalent interaction properties towards G-quadruplex, Biochemie 93 (2011) 1328-1340, doi: https://doi.org/10.1016/j.biochi.2011.06.015; (b) F. Doria, M. Nadai, M. Folini, M. Di Antonio, L. Germani, C. Percivalle, C. Sissi, N. Zaffaroni, S. Alcaro, A. Artese, S. N. Richter, M. Freccero, Hybrid ligandalkylating agents targeting telomeric G-quadruplex structures, Org. Biomol. Chem. 10 (2012) 2798-2806, doi: https://doi. org/10.1039/C2OB06816H; (c) F. Doria, M. Nadai, M. Folini, M. Scalabrin, L. Germani, G. Sattin, M. Mella, M. Palumbo, N. Zaffaroni, D. Fabris, M. Freccero, S. N. Richter, Targeting Loop Adenines in G-Quadruplex by a Selective Oxirane, Chem. Eur. J. 19 (2013) 78-81, doi: https://doi.org/10.1002/ chem. 201203097.

51. F. Doria, A. Lena, R. Bargiggia, M. Freccero, Conjugation, Substituent, and Solvent Effects on the Photogeneration of Quinone Methides, J. Org. Chem. 81 (2016) 3665-3673, doi: https://doi.org/10.1021/acs.joc.6b00331.

52. E. Rommel, J. Wirz, The photoenol tautomer of 5-methyl-1, 4-naphthoquinone, Helv. Chim. Acta. 60 (1977) 38-42, doi: https://doi.org/10.1002/hlca.19770600106.

53. H. Kang, S. E. Rokita, Site-Specific and Photo-Induced Alkylation of DNA by a Dimethylanthraquinone-Oligodeoxynucleotide Conjugate, Nucl. Acid. Res. 24 (1996) 3896-3902, doi: https://doi.org/10.1093/nar/24.20.3896.

54. (a) R. S. Givens, D. Heger, B. Hellrung, Y. Kamdzhilov, M. Mac, P. G. Conrad, E. Cope, J. I. Lee, J. F. Mata-Segrada, R. L. Cshowen, J. Wirz, The Photo-Favorskii Reaction of $p$-Hydroxyphenacyl Compounds Is Initiated by Water-Assisted, Adiabatic Extrusion of a Triplet Biradical, J. Am. Chem. Soc. 130 (2008) 3307-3309, doi: https://doi.org/10.1021/ja7109579; (b) M. Xu, M. Lukeman, P. Wan, Photodecarboxylation of benzoyl-substituted biphenylacetic acids and photo-retro-Aldol reaction of related compounds in aqueous solution. Acid and base catalysis of reaction, J. Photochem. Photobiol. A: Chem. 204 (2009) 52-62, doi: https://doi.org/S1010603009000793; (c) H.-Y. An, W. M. Kwok, C. Ma, X. Guan, J. T. W. Kan, P. H. Toy, D. L. Philips, Photophysics and Photodeprotection Reactions of $p$-Methoxyphenacyl Phototriggers: An Ultrafast and Nanosecond Time-Resolved Spectroscopic and Density Functional Theory Study, J. Org. Chem. 75 (2010) 5837-5851, doi: https://doi.org/10.1021/jo100848b.

55. (a) L. Klíčová; P. Šebej, T. Šolomek, B. Hellrung, P. Slavíček, P. Klán, D. Heger, J. Wirz, Adiabatic Triplet State Tautomerization of p-Hydroxyacetophenone in Aqueous Solution, J. Phys. Chem. A 116 (2012) 2935-2944, doi: https://doi. org/10.1021/jp3011469; (b) B. P. Ngoy, P. Šebej, T. Šolomek,
B. H. Lim, T. Pastierik, B. S. Park, R. S. Givens, D. Heger, P. Klán, 2-Hydroxyphenacyl ester: a new photoremovable protecting group, Photochem. Photobiol. Sci. 11 (2012) 1465-1475, doi: https://doi.org/10.1039/c2pp25133g.

56. P. Kalnderopoulos, K. Yates, Intramolecular proton transfer in photohydration reactions, J. Am. Chem. Soc. 108 (1986) 6290-6295, doi: https://doi.org/10.1021/ja00280a028.

57. (a) K. L. Foster, S. Baker, D. W. Brousmiche, P. Wan, o-Quinone methide formation from excited state intramolecular proton transfer (ESIPT) in an o-hydroxystyrene, J. Photochem. Photobiol. A: Chem. 129 (1999) 157-163, doi: https://doi. org/10.1016/S1010-6030(99)00192-6; (b) M. Fischer, P. Wan, $m$-Quinone Methides from m-Hydroxy-1,1-Diaryl Alkenes via Excited-State (Formal) Intramolecular Proton Transfer Mediated by a Water Trimer, J. Am. Chem. Soc. 120 (1998) 2680-2681, doi: https://doi.org/10.1021/ja974144y; (c) M. Fischer, P. Wan, Nonlinear Solvent Water Effects in the Excited-State (Formal) Intramolecular Proton Transfer (ESIPT) in $m$-Hydroxy-1,1-diaryl Alkenes: Efficient Formation of $m$-Quinone Methides, J. Am. Chem. Soc. 121 (1999) 4555-4562, doi: https://doi.org/10.1021/ja983557b.

58. T. Murohoshi, K. Kaneda, M. Ikegami, T. Arai, Photoisomerization and isomer-specific addition of water in hydroxystilbenes, Photochem. Photobiol. Sci. 2 (2003) 1247-1249, doi: https://doi.org/10.1039/B307957K.

59. (a) M. Lukeman, P. Wan, Excited state intramolecular proton transfer (ESIPT) in 2-phenylphenol: an example of proton transfer to a carbon of an aromatic ring, Chem. Commun. (2001) 1004-1005, doi: https://doi.org/10.1039/B100817J; (b) M. Lukeman, P. Wan, A New Type of Excited-State Intramolecular Proton Transfer: Proton Transfer from Phenol OH to a Carbon Atom of an Aromatic Ring Observed for 2-Phenylphenol, J. Am. Chem. Soc. 124 (2002) 9458-9464, doi: https://doi.org/10.1021/ja0267831.

60. (a) M. Lukeman, D. Veale, P. Wan, V. R. Munasinghe, J. E. T. Corrie, Photogeneration of 1,5-naphthoquinone methides via excited-state (formal) intramolecular proton transfer (ESIPT) and photodehydration of 1-naphthol derivatives in aqueous solution, Can. J. Chem. 82 (2004) 240-253, doi: https:// doi.org/0.1139/V03-184; (b) S. P. Webb, L. A. Philips, S. W. Yeh, L. M. Tolbert, J. H. Clark, Picosecond kinetics of the excited-state, proton-transfer reaction of 1-naphthol in water, J. Phys. Chem. 90 (1986) 5154-5164, doi: https://doi. org/10.1021/j100412a053.

61. (a) M. Lukeman, P. Wan, Excited-State Intramolecular Proton Transfer in o-Hydroxybiaryls: A New Route to Dihydroaromatic Compounds, J. Am. Chem. Soc. 125 (2003) 11641165, doi: https://doi.org/10.1021/ja029376y; (b) N. Basarić, N. Došlić, J. Ivković, Y. H. Wang, M. Mališ, P. Wan, Very Efficient Generation of Quinone Methides through Excited State Intramolecular Proton Transfer to a Carbon Atom, Chem. Eur. J. 18 (2012) 10617-10623, doi: https://doi.org/10.1002/ chem.201201144.

62. M. Flegel, M. Lukeman, P. Wan, Photochemistry of 1,1'-bi-2naphthol (BINOL): ESIPT is responsible for photoracemization and photocyclization, Can. J. Chem. 86 (2008) 161-169, doi: https://doi.org/10.1139/v07-143.

63. M. Kumar, P. Wan, Direct and water-mediated excited state intramolecular proton transfer (ESIPT) from phenol $\mathrm{OH}$ to carbon atoms of extended ortho-substituted biaryl systems, Photochem. Photobiol. Sci. 7 (2008) 1544-1554, doi: https:// doi.org/10.1039/b810111f.

64. M. Lukeman, M.-D. Burns, P. Wan, Excited state intramolecular proton transfer in 1-hydroxypyrene, Can. J. Chem. 89 (2011) 433-440, doi: https://doi.org/10.1139/V11-010.

65. (a) M. Flegel, M. Lukeman, L. Huck, P. Wan, Photoaddition of Water and Alcohols to the Anthracene Moiety of 9-(2'-Hydroxyphenyl)anthracene via Formal Excited State Intramolecular Proton Transfer, J. Am. Chem. Soc. 126 (2004) 78907897, doi: https://doi.org/10.1021/ja039078g; (b) N. Basarić, 
P. Wan, Competing Excited State Intramolecular Proton Transfer Pathways from Phenol to Anthracene Moieties, J. Org. Chem. 71 (2006) 2677-2686, doi: https://doi.org/10.1021/ jo0524728; (c) Y.-H. Wang, P. Wan, Excited state intramolecular proton transfer (ESIPT) in dihydroxyphenyl anthracenes, Photochem. Photobiol. Sci. 10 (2011) 1934-1944, doi: https://doi.org/10.1039/c1pp05187c.

66. (a) M. Isaks, K. Yates, P. Kalanderopoulos, Photohydration via intramolecular proton transfer to carbon in electronically excited states, J. Am. Chem. Soc. 106 (1984) 2728-2730, doi: https://doi.org/10.1021/ja00321a058; (b) F. Doria, C. Percivalle, M. Freccero, Vinylidene-Quinone Methides, Photochemical Generation and $\beta$-Silicon Effect on Reactivity, J. Org. Chem. 77 (2012) 3615-3619, doi: https://doi.org/10.1021/ jo300115f.

67.P. G. McCracken, J. L. Bolton, G. R. J. Thatcher, Covalent Modification of Proteins and Peptides by the Quinone Methide from 2-tert-Butyl-4,6-dimethylphenol: Selectivity and Reactivity with Respect to Competitive Hydration, J. Org. Chem. 62 (1997) 1820-1825, doi: https://doi.org/10.1021/ jo962088y.

68. S. Arumugam, J. Guo, N. E. Mbua, F. Friscourt, N. Lin, E. Nekongo, G.-J. Boons, V. V. Popik, Selective and reversible photochemical derivatization of cysteine residues in peptides and proteins, Chem. Sci. 5 (2014) 1591-1598, doi: https://doi. org/10.1039/C3SC51691A.

69. J. L. Bolton, S. B. Turnipseed, J. A. Thompson, Influence of quinone methide reactivity on the alkylation of thiol and amino groups in proteins: studies utilizing amino acid and peptide models, Chem.-Biol. Interact. 107 (1997) 185-200, doi: https://doi.org/10.1016/S0009-2797(97)00079-3.

70. (a) Q. Zeng, S. E. Rokita, Tandem Quinone Methide Generation for Cross-Linking DNA, J. Org. Chem. 61 (1996) 9080-9081, doi: https://doi.org/10.1021/jo961864z; (b) S. E. Rokita, J. Yang, P. Pande, W. A. Greenberg, Quinone Methide Alkylation of Deoxycytidine, J. Org. Chem. 62 (1997) 30103012, doi: https://doi.org/10.1021/jo9700336; (c) W. F. Veldhuyzen, A. J. Shallop, R. A. Jones, S. E. Rokita, Thermodynamic versus Kinetic Products of DNA Alkylation as Modeled by Reaction of Deoxyadenosine, J. Am. Chem. Soc. 123 (2001) 11126-11132, doi: https://doi.org/10.1021/ja011686d; (d) W. F. Veldhuyzen, P. Pande, S. E. Rokita, A Transient Product of DNA Alkylation Can Be Stabilized by Binding Localization, J. Am. Chem. Soc. 125 (2003) 14005-14013, doi: https://doi. org/10.1021/ja036943o; (e) Q. Zhou, S. E. Rokita, A general strategy for target-promoted alkylation in biological systems, Proc. Natl. Acad. Sci. U.S.A. 100 (2003) 15452-15457, doi: https://doi.org/10.1073/pnas.2533112100; (f) E. E. Weinert, K. N. Frankenfield, S. E. Rokita, Time-dependent evolution of adducts formed between deoxynucleosides and a model quinone methide., Chem. Res. Toxicol. 18 (2005) 1364-1370, doi: https://doi.org/10.1021/tx0501583; (g) H. Wang, M. S. Wahi, S. E. Rokita, Immortalizing a Transient Electrophile for DNA Cross-Linking, Angew. Chem., Int. Ed. 47 (2008) 12911293, doi: https://doi.org/10.1002/anie.200704137; (h) H. Wang, S. E. Rokita, Dynamic Cross-Linking Is Retained in Duplex DNA after Multiple Exchange of Strands, Angew. Chem., Int. Ed. 49 (2010) 5957-5960, doi: https://doi.org/10.1002/ anie.201001597; (i) C. S. Rossiter, E. Modica, D. Kumar, S. E. Rokita, Few constraints limit the design of quinone methide-oligonucleotide self-adducts for directing DNA alkylation, Chem. Commun. 47 (2011) 1476-1478, doi: https:// doi.org/10.1039/c0cc03317k.

71. (a) I. A. McDonald, P. L. Nyce, M. J. Jung, J. S. Sabol, Syntheses of DL-2-fluoromethy-p-tyrosine and DL-2-difluoromethyl-p-tyrosine as potential inhibitors of tyrosine hydroxylase, Tetrahedron Lett. 32 (1991) 887-890, doi: https://doi. org/10.1016/S0040-4039(00)92112-9; (b) Q. Wang, J. K. Myers, J. D. Cohen, T. S. Widlanski, Substituent Effects on the Mechanism-Based Inactivation of Prostatic Acid Phosphatase,
J. Am. Chem. Soc. 117 (1995) 11049-11054, doi: https://doi. org/10.1021/ja00150a002; (c) J. K. Storwell, T. S. Widlanski, T. G. Kutaleladze, R. T. Raines, Mechanism-based inactivation of ribonuclease A, J. Org. Chem. 60 (1995) 6930-6936, doi: https://doi.org/10.1021/jo00126a051; (d) D. Cabaret, S. A. Adediran, M. J. G. Gonzalez, R. F. Pratt, M. Wakselman, Synthesis and Reactivity with $\beta$-Lactamases of "Penicillin-like" Cyclic Depsipeptides, J. Org. Chem. 64 (1999) 713-720, doi: https://doi.org/10.1021/jo980564+.

72. (a) P. Wang, Y. Song, L. Zhang, H. He, X. Zhou, Quinone Methide Derivatives: Important Intermediates to DNA Alkylating and DNA Cross-linking Actions, Curr. Med. Chem. 12 (2005) 2893-2913, doi: https://doi. org/10.2174/092986705774454724; (b) M. Freccero, Quinone Methides as Alkylating and Cross-Linking Agents, Mini Rev. Org. Chem. 1 (2004) 403-415, doi: https://doi. org/10.2174/1570193043403091.

73. S. E. Wolkenberg, D. L. Boger, Mechanisms of in Situ Activation for DNA-Targeting Antitumor Agents, Chem. Rev. 102 (2002) 2477-2495, doi: https://doi.org/10.1021/cr010046q.

74. (a) V. S. Li, H. Kohn, Studies on the bonding specificity for mitomycin C-DNA monoalkylation processes, J. Am. Chem. Soc. 113 (1991) 275-283, doi: https://doi.org/10.1021/ ja00001a040; (b) I. Han, D. J. Russell, H. Kohn, Studies on the mechanism of mitomycin C(1) electrophilic transformations: structure-reactivity relationships, J. Org. Chem. 57 (1992) 1799-1807, doi: https://doi.org/10.1021/jo00032a037; (c) M. Tomasz, A. Das, K. S. Tang, M. G. J. Ford, A. Minnock, S. M. Musser, M. J. Waring, The Purine 2-Amino Group as the Critical Recognition Element for Sequence-Specific Alkylation and Cross-Linking of DNA by Mitomycin C, J. Am. Chem. Soc. 120 (1998) 11581-11593, doi: https://doi.org/10.1021/ ja9824019.

75. C. Tan, H. Tasaka, K.-P. Yu, M. L. Murphy, D. A. Karnofsky, Daunomycin, an antitumor antibiotic, in the treatment of neoplastic disease. Clinical evaluation with special reference to childhood leukemia, Cancer 20 (2006) 333-353, doi: https:// doi.org/10.1002/1097-0142(1967)20:3<333::AID-CNCR2820200302>3.0.CO;2-K.

76. (a) F. A. Fornari, J. K. Randolph, J. C. Yalowich, M. K. Ritke, D. A. Gewirtz, Interference by doxorubicin with DNA unwinding in MCF-7 breast tumor cells, Mol. Pharmacol. 45 (1994) 649-656; (b) R. L. Momparler, M. Karon, S. E. Siegel, F. Avila, Effect of adriamycin on DNA, RNA, and protein synthesis in cell-free systems and intact cells, Cancer Res. 38 (1976) 2891-2895.

77. J. M. Berg, J. L. Tymoczko, L. Stryer, Biochemistry, 6. izdanje, W. H. Freeman and Company, New York, 2007, str. 791-792.

78. T. H. Koch, B. L. Barthel, B. T. Kalet, D. L. Rudnicki, G. C. Post, D. J. Burkhart, Anthracycline-Formaldehyde Conjugates and Their Targeted Prodrugs, Top. Curr. Chem. 283 (2008) 141-170, doi: https://doi.org/10.1007/128_2007_4.

79 (a) D. L. Boger, D. S. Johnson, CC-1065 and the duocarmycins: unraveling the keys to a new class of naturally derived DNA alkylating agents, Proc. Natl. Acad. Sci. USA 92 (1995) 36423649, doi: https://doi.org/10.1073/pnas.92.9.3642; (b) M. A. Warpehoski, D. E. Harper, Acid-Dependent Electrophilicity of Cyclopropylpyrroloindoles. Nature's Masking Strategy for a Potent DNA Alkylator, J. Am. Chem. Soc. 116 (1994) 7573-7580, doi: https://doi.org/10.1021/ja00096a014; (c) D. L. Boger, B. Bollinger, D. L. Hertzog, D. S. Johnson, $H$. Cai, P. Mésini, R. M. Garbaccio, Q. Jin, P. A. Kitos, Reversed and Sandwiched Analogs of Duocarmycin SA: Establishment of the Origin of the Sequence-Selective Alkylation of DNA and New Insights into the Source of Catalysis, J. Am. Chem. Soc. 119 (1997) 4987-4998, doi: https://doi.org/10.1021/ ja9637210; (d) D. L. Boger, A. Santillán Jr., M. Searcey, Q. Jin, Critical Role of the Linking Amide in CC-1065 and the Duocarmycins: Implications on the Source of DNA Alkylation Catalysis, J. Am. Chem. Soc. 120 (1998) 11554-11557, doi: 
https://doi.org/10.1021/ja9818093.

80. N. Hoffmann, Photochemical reactions of aromatic compounds and the concept of the photon as a traceless reagent, Photochem. Photobiol. Sci. 11 (2012) 1613-1641, doi: https://doi.org/10.1039/C2PP25074H.

81. (a) D. Bethea, B. Fullmer, S. Syed, G. Seltzer, J. Tiano, C. Rischko, L. Gillespie, D. Brown, F. P Gasparro, Psoralen photobiology and photochemotherapy: 50 years of science and medicine, J. Dermatol. Sci. 19 (1999) 78-88, doi: https://doi. org/10.1016/S0923-1811(98)00064-4; (b) M. E. Tamesis, M. G Morelli, Vitiligo Treatment in Childhood: A State of the Art, Review Pediatr Dermatol 27 (2010) 437-445, doi: https:// doi.org/10.1111/j.1525-1470.2010.01159.x.

82. J. Chen, L. Keltner, J. Christophersen, F. Zheng, M. Krouse, A. Singhal, S.-S. Wang, New technology for deep light distribution in tissue for phototherapy, Cancer J. 8 (2002) 154-163, doi: https://doi.org/10.1097/00130404-200203000-00009.

83. T. S. Mang, Lasers and light sources for PDT: past, present and future, Photodiagnosis Photodyn Ther 1 (2004) 43-48, doi: https://doi.org/10.1016/S1572-1000(04)00012-2.

84. A. Griesbeck, M. Oelgemöller, F. Ghetti (ur.), Handbook of organic photochemistry and photobiology, CRC Press, Boca Raton, 3. izdanje, 2012, poglavlja 62 i 64.

85. (a) J. K. Myers, J. D. Cohen, T. S. Widlanski, Substituent Effects on the Mechanism-Based Inactivation of Prostatic Acid Phosphatase, J. Am. Chem. Soc. 117 (1995) 11049-11054, doi: https://doi.org/10.1021/ja00150a002; (b) S.-K. Chung, J. W. Lee, N. Y. Shim, T. W. Kwon, p-Quinone methides as geometric analogues of quinolone carboxylate antibacterials, Bioorg. Med. Chem. Lett. 6 (1996) 1309-1312, doi: https://doi.org/1 0.1016/0960-894X(96)00218-1.

86. J. Jiang, D. Zeng, S. Li, Photogenerated Quinone Methides as Protein Affinity Labeling Reagents, ChemBioChem. 10 (2009) 635-638, doi: https://doi.org/10.1002/cbic.200800700.

87. E. B. Skibo, C. Xing, Chemistry and DNA alkylation reactions of aziridinyl quinones: development of an efficient alkylating agent of the phosphate backbone, Biochemistry 37 (1998) 15199-15213, doi: https://doi.org/10.1021/bi981204j.

88. Q. Zhuo, K. D. Turnbull, Phosphodiester Alkylation with a Quinone Methide, J. Org. Chem. 64 (1999) 2847-2851, doi: https://doi.org/10.1021/jo9823745.
89. (a) Q. Zhou, K. D. Turnbull, Trapping Phosphodiester-Quinone Methide Adducts through in Situ Lactonization, J. Org. Chem. 65 (2000) 2022-2029, doi: https://doi.org/10.1021/ jo9915168; (b) Q. Zhou, K. D. Turnbull, Quinone Methide Phosphodiester Alkylations under Aqueous Conditions, J. Org. Chem. 66 (2001) 7072-7077, doi: https://doi.org/10.1021/ jo015792+; (c) B. A. Bakke, M. C. Mclntosh, K. D. Turnbull, Improved Alkylation and Product Stability in Phosphotriester Formation through Quinone Methide Reactions with Dialkyl Phosphates, J. Org. Chem. 70 (2005) 4338-4345, doi: https://doi.org/10.1021/jo050050s.

90. P. Pande, J. Shearer, J. Yang, W. Greenbern, S. E. Rokita, Alkylation of Nucleic Acids by a Model Quinone Methide, J. Am. Chem. Soc. 121 (1999) 6773-6779, doi: https://doi. org/10.1021/ja990456k.

91. M. A. Lewis, D. Graff Yoerg, J. L. Bolton, J. A. Thompson, Alkylation of 2'-Deoxynucleosides and DNA by Quinone Methides Derived from 2,6-Di-tert-butyl-4-methylphenol, Chem. Res. Toxicol. 9 (1996) 1368-1374, doi: https://doi. org/10.1021/tx960115+.

92. Q. Zhou, Y. Qu, J. B. Mangrum, X. Wang, DNA Alkylation with N-Methylquinolinium Quinone Methide to N2-dG Adducts Resulting in Extensive Stops in Primer Extension with DNA Polymerases and Subsequent Suppression of GFP Expression in A549 Cells, Chem. Res. Toxicol. 24 (2011) 402-411, doi: https://doi.org/10.1021/tx100351c.

93. H. He, T. Tian, P. Wang, L. Wu, J. Xu, X. Zhou, X. Zhang, X. Cao, $X$. $W u$, Porphyrin-DNA cross-linking agent hybrids: chemical synthesis and biological studies, Bioorg. Med. Chem. Lett. 14 (2004) 3013-3016, doi: https://doi.org/10.1016/j. bmcl.2004.04.044.

94. (a) J. B. Chaires, Energetics of drug-DNA interactions, Biopolymers 44 (1997) 201-215, doi: https://doi.org/10.1002/ (SICI)1097-0282(1997)44:3<201::AID-BIP2>3.0.CO;2-Z; (b) R. Palchaudhuri, P. J. Hergenrother, DNA as a target for anticancer compounds: methods to determine the mode of binding and the mechanism of action, Curr. Opin. Biotechnol. 18 (2007) 497-503, doi: https://doi.org/10.1016/j.copbio.2007.09.006.

\title{
SUMMARY
}

\section{Quinone Methides (Part II): Photochemical Generation and Development of Applications in Photochemotherapy \\ Đani Škalamera, Antonija Husak, and Tatjana Šumanovac Ramljak}

\begin{abstract}
Quinone-methides (QMs, IUPAC name: quinomethanes) are reactive intermediates that are associated with the biological activity of numerous natural and synthetic compounds. Their activity is based on the inhibition of enzymes or, more often, on the alkylation/cross-linking of DNA. QMs can be generated by thermal methods, but photochemical methods have great advantages because they provide the possibility of spatial and temporal control over their generation. For the final goal - application in photochemotherapy, the development of precursors for the generation of QMs is crucial. This review will provide insight into the photochemical methods of generating QMs and development of their use in photochemotherapy.
\end{abstract}

\section{Keywords}

Quinone methides, reactive intermediates, photochemical generation of quinone methides, antiproliferative activity, DNA alkylating agents, DNA cross-linking, photochemotherapy 